\title{
Nature and origin of large-scale and intrasalt deformation within the Wieliczka salt mine, Poland
}

\author{
Mark G. ROWAN ${ }^{1}$ *, Piotr KRZYWIEC ${ }^{2}$, Krzysztof BUKOWSKI ${ }^{3}$ and Jerzy PRZYBYŁO ${ }^{4}$ \\ 1 Rowan Consulting, Inc. 850 8th St., Boulder, CO 80302, USA \\ 2 Polish Academy of Sciences, Institute of Geological Sciences, Twarda 51/55, 00-818 Warszawa, Poland \\ 3 AGH University of Science and Technology, Faculty of Geology, Geophysics and Environmental Protection, \\ al. A. Mickiewicza 30, 30-059 Kraków, Poland \\ 4 Kopalnia Soli "Wieliczka" S.A., Park Kingi 1, 32-020 Wieliczka, Poland
}

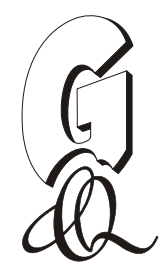

Rowan, M.G., Krzywiec, P., Bukowski, K., Przybyło, J., 2020. Nature and origin of large-scale and intrasalt deformation within the Wieliczka salt mine, Poland. Geological Quarterly, 64 (4): 819-837, doi: 10.7306/gq.1557

\begin{abstract}
The Wieliczka salt mine, near Kraków in southern Poland, is a world-famous historical and modern destination for both geoscientists and tourists. Despite numerous publications, there is still a lack of consensus on the nature and origin of the large-scale folds as well as whether the small-scale structures represent tectonic or soft-sediment deformation. In this preliminary work, we offer new ideas on both aspects. At the large scale, we emphasize the mechanical stratigraphy of the layered evaporite sequence, which comprises a thin basal weak layer, a thin strong unit, a thicker weak layer, and a thicker strong unit. We suggest that the inclined to recumbent folds and thrusts formed tectonically due to overthrust shear between the basal detachment and the overriding Carpathian frontal thrust, with different structural styles decoupled by the thick weak layer. At the small scale, we suggest that there was early extension directed toward the east to north-east, followed by contraction vergent toward the north. We infer that there was early, syndepositional gravity gliding down a topographic slope dipping into the coeval Gdów depocenter to the east, and that subsequent north-directed Carpathian shortening generated the small-scale contractional structures as the larger folds were developing.
\end{abstract}

Key words: salt tectonics, intrasalt deformation, salt mine, Wieliczka, northern Carpathians.

\section{INTRODUCTION}

The Wieliczka salt mine, located just $12 \mathrm{~km}$ south-east of the centre of Kraków, Poland, is a world-famous cultural site that was added to UNESCO's World Heritage List in 1978 (https://whc.unesco.org/en/list/), just after the list was established. It has long been regarded as a classic geologic locality, with excellent exposures of fold structures within Miocene evaporites deposited in the Carpathian Foredeep. Underground operations at Wieliczka salt mine started in the 13th century. Since then, $>300 \mathrm{~km}$ of shafts, galleries, and corridors have been excavated in the mine, including chambers located within gigantic, cathedral-size boulders of almost pure halite.

Wieliczka has appeared relatively frequently in the literature of previous centuries. In the second half of the 16th century a poem was published in Latin that was entirely devoted to the Wieliczka "abyss" (Schröter, 1564; cf. Maślankiewicz, 1965). Illustrations of salt crystals from Wieliczka were published by Ulisse Aldrovandi, often referred to as a father of

\footnotetext{
* Corresponding author, e-mail: mgrowan@frii.com Received: June 19, 2020; accepted: August 18, 2020; first published online: September 29, 2020
}

studies of natural history (Aldrovandi, 1648). Soon after, a travelogue by a "Curious Gentleman of Germany" that contained some remarks on the types of salt appeared in the Philosophical Transactions of the Royal Society (Anonym, 1670). A large, beautifully executed cross-section of the surface and subsurface salt works was included in the 7th volume of the famous Encyclopedia edited by Denis Diderot and Jean le Rond d'Alembert (Bénard, 1768).

Centuries of active exploitation of salt resulted in the exposure of numerous underground outcrops where various complex salt structures could be observed. The first publication that contained illustrations of these structures and their description, including some proto-geological remarks regarding the types of salt and an overall structural style, was published by Schober (1750; see also Boczkowski, 1843; Zejszner, 1843; Siemion, 1991). His descriptions of lithological variations and structural styles of the salt and surrounding rocks are very accurate, and his sketches depict structures that can be still admired in the mine (Fig. 1A, B). He also focused his attention on the nature of the salt layers, linking the origin of rock salt to marine conditions as suggested by occurrences of remnants of marine organisms.

Intense mining in the late 18th and early 19th centuries resulted in the accumulation of considerable data on the spatial location and orientations of various salt layers, salt boulders, and interbedded barren rocks. This allowed for construction of fairly detailed cross-sections depicting the general structure of 

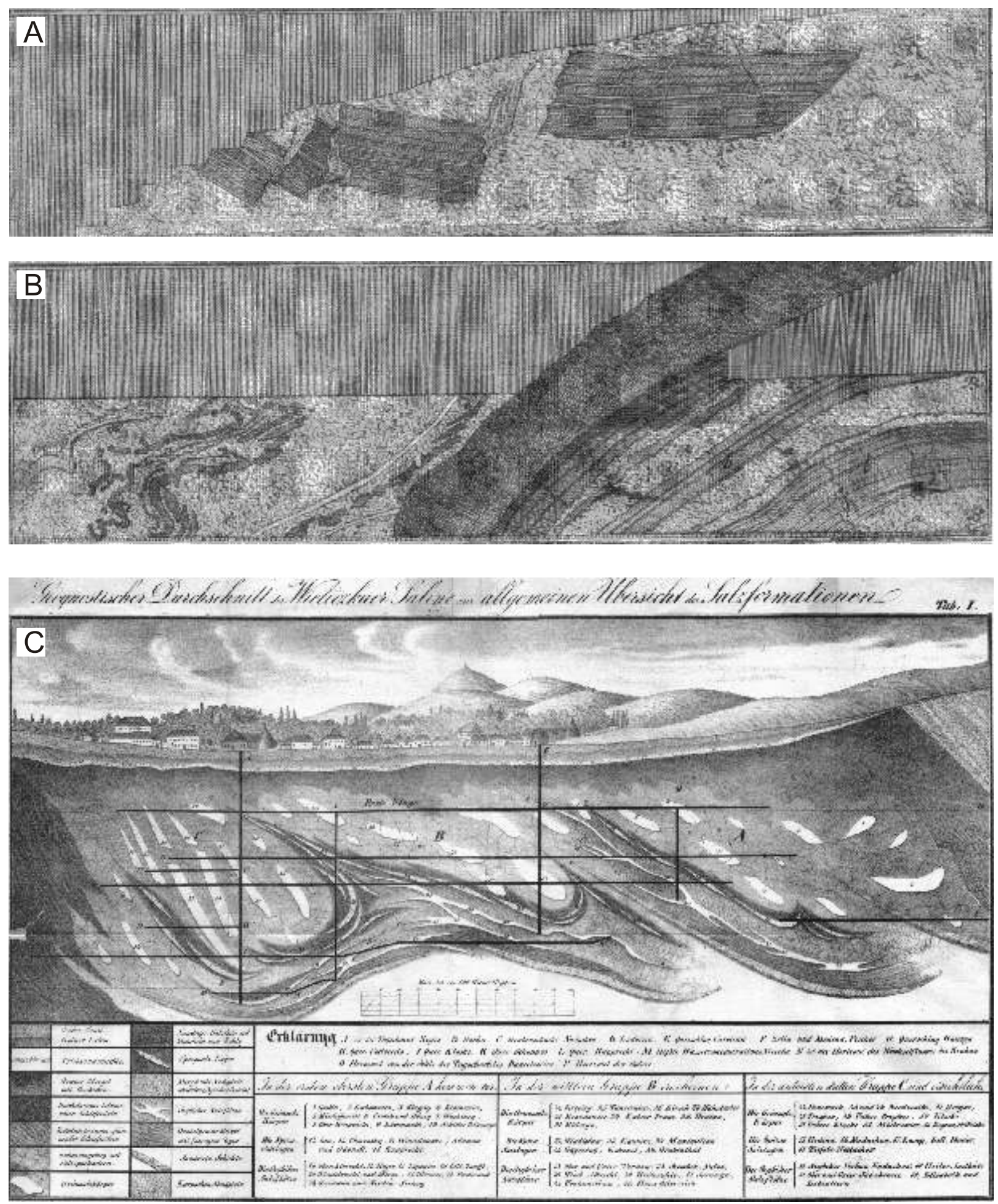

\section{Fig. 1. Historical drawings of the Wieliczka salt mine}

A - sketch of rotated and faulted boudins of strong layer within halite matrix (Schober, 1750); B - sketch of broad fold on right, overlapping boudins left of centre, and disharmonically folded boudinaged layers at the left (Schober, 1750); C - cross-section showing surface features and the subsurface structure (north to the left) with folded stratified salt and overlying isolated blocks of halite (Hrdina and Hrdina, 1842) 
the Carpathian Foredeep in the Wieliczka area (Hrdina and Hrdina, 1842; Zejszner, 1843; cf. Maślankiewicz, 1965; Poborski, 1965). The beautifully executed cross-section by Hrdina and Hrdina (1842), depicting not only the subsurface geology but also the surface morphology and key buildings of Wieliczka, is illustrated in Figure $1 \mathrm{C}$. It clearly shows three slivers with repeated sequences of key rock types - a common feature of most modern cross-sections across Wieliczka as well. In the second half of the 19th century, Niedźwiedzki (1883-1886) published a series of papers on rock-bearing deposits of the Carpathian Foredeep together with several geological crosssections that were, however, considerably less detailed than those by Hrdina and Hrdina and Zejszner (cf. Maślankiewicz, 1965; Poborski, 1965).

The mine has also been the subject of intensive study in more recent times, with most of the research devoted to stratigraphic and structural aspects (e.g., Tołwiński, 1956; Gaweł, 1962; Poborski and Skoczylas-Ciszewska, 1963; Szybist, 1975; Garlicki, 1979; Wiewiórka, 1979, 1988; Kolasa and Ślaczka, 1985a, b; Tarka et al., 1988; Tarka, 1992; Ślączka and Kolasa, 1997; Bukowski, 1997; Brudnik et al., 2000; Krzywiec and Vergés, 2007; Cyran, 2008; Gonera et al., 2012; Burliga et al., 2018). The Wieliczka Formation is a layered evaporite sequence (LES) comprising halite, anhydrite, and siliciclastic rocks. Note that we use the term salt to denote the entire LES, analogous to a salt diapir denoting a body of rock comprising a mixture of evaporites and non-evaporite stringers (e.g., Rowan et al., 2019 and many others). In contrast, we use halite and anhydrite to refer to beds or clasts comprised mostly/entirely of $\mathrm{NaCl}$ or $\mathrm{CaSO}_{4}$, respectively. Thus, when we use the term "intrasalt" deformation, we refer to structures affecting any part of the LES, not solely to folds and shear zones within the halite beds.

The layers within the LES are characterized by widely varying structural styles at a variety of scales, including folds, thrusts, extensional faults, boudins, veins, and joints (Fig. 1; cf. e.g., Tarka et al., 1988; Tarka, 1992; Burliga et al., 2018). The origin of the deformation is the subject of ongoing debate, with two key aspects still unresolved. First, what is the detailed geometry of the large-scale deformation of the entire LES and how did it develop? The various published cross-sections show the predominance of asymmetric folds, but as yet there is no satisfactory explanation of their genesis and the role of the mechanical stratigraphy in controlling the structural style, and depictions of the deep geometry are rare. Second, how much of the small-scale deformation is tectonic in origin and how much is the result of soft-sediment deformation during deposition of the LES? There is evidence for both, but can we distinguish between the two processes?

The goal of this paper is to address both these issues from a primarily structural perspective. We first summarize the existing literature on the regional tectonic setting, the lithostratigraphy of the salt and encasing rocks, and the small-scale deformation. We then illustrate the observed structural styles in a small area within the upper portion of the mine before turning to the analysis of the geometries. At the large scale, we evaluate the published cross-sections - effectively an interpretation of existing interpretations - and identify the Wieliczka Formation as a multilayer (a sequence of strata with different thicknesses and competencies) subjected to overthrust shear, with folds and thrusts controlled by the mechanical stratigraphy between two diverging shear detachments. At the small scale, we suggest that there was early extension due to gravity-driven sediment remobilization down an east- to northeast-dipping topographic slope into the "Gdów Embayment", followed by north-directed contractional deformation related to emplacement of the
Carpathian frontal thrust nappe. We emphasize that these results are preliminary, in that they are based only on limited data, and need to be tested and refined with further data collection and analysis. Thus, we outline several avenues of possible future research that might be undertaken in order to better understand the structure and evolution of the Wieliczka segment of the frontal Carpathian orogenic wedge. Since the Wieliczka salt mine is one of the "natural wonders of the world", any further work is surely warranted.

\section{GEOLOGIC SETTING}

\section{REGIONAL STRUCTURE AND TECTONICS}

The frontal Carpathian nappes extend from the Czech Republic, Slovakia and Poland in the west, into Ukraine, and curve around into Romania (see e.g., Roure et al., 1993; Nemčok et al., 2006; and Ślączka et al., 2006 for detailed overviews and numerous further references). In southern Poland, the fold-and-thrust belt has an overall E-W trend and is bounded to the north by the Carpathian Foredeep (Figs. 2 and 3). The outer nappes, comprising primarily Cretaceous and Paleogene flysch deposits, were thrust to the north during the Miocene (see Oszczypko et al., 2006 for a review and further references). Coeval development of a foreland basin gradually shifted to the north in front of and beneath the advancing nappes due primarily to thrust loading but also to depositional loading. The foredeep was filled with uppermost Oligocene to Middle Miocene mostly marine siliciclastic successions, including the Middle Miocene Wieliczka Formation during the so-called "Badenian Salinity Crisis" (BSC), a time of basin isolation caused by a major fall in sea level and climatic cooling (Oszczypko et al., 2006; Peryt, 2006; de Leeuw et al., 2010). The synorogenic sediments progressively onlapped the substratum toward the north (e.g., Oszczypko, 1997, 1998; Krzywiec, 2001; Oszczypko et al., 2006).

The floor of the foredeep was an erosional unconformity underlain by Mesozoic and Paleozoic rocks of the North European Platform. This surface had significant topographic relief that took three forms. First, there was a general deepening to the south due to loading by the Carpathian nappes, as in any foreland basin. Second, there were more local lows that formed due to basement faulting and tectonic subsidence associated with the loading-induced flexure of the crust. One such example is the so-called Gdów Embayment, an area between the Wieliczka and Bochnia salt mines (Fig. 2) filled with an abnormally thick sequence of the presalt Skawina Formation (Alexandrowicz, 1965; Garlicki, 1971; Krzywiec et al., 2012). Third, a series of narrower lows in the unconformity represent N-S to NW-SE trending palaeovalleys, deepening toward the south, incised into the underlying basement (e.g., Jucha, 1974; Krzywiec, 2001; Krzywiec et al., 2004, 2008, 2014; Głuszyński and Aleksandrowski, 2016; Gedl and Worobiec, 2020). Whatever the origin of the topographic relief, it influenced evaporite deposition, with halite-dominated facies in the lows and anhydrite-dominated facies on higher, marginal areas of the salt basin (e.g., Garlicki, 1979; Peryt, 2006; Krzywiec et al., 2008; Bukowski, 2011; Głuszyński and Aleksandrowski, 2016). The distribution of evaporite facies in turn impacted thrust geometries of the frontal Carpathian orogenic wedge (e.g., Połtowicz, 1994, 2004; Krzywiec, 2001; Krzywiec et al., 2014; Głuszyński and Aleksandrowski, 2016).

The Wieliczka salt mine is located directly in front (north) of the surface expression of the Carpathian thrust front (Figs. 2 


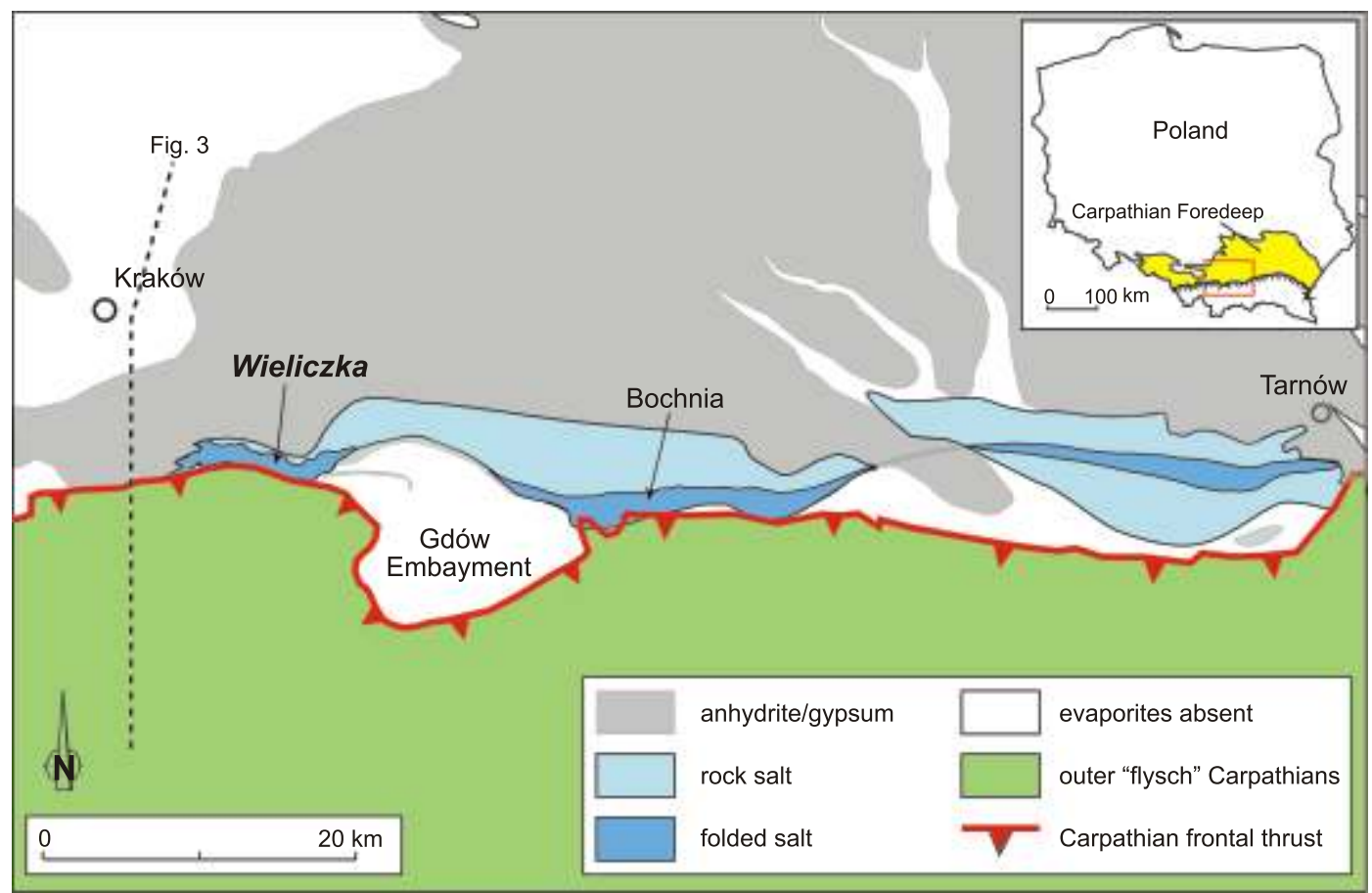

Fig. 2. Simplified geologic map showing distribution of Miocene evaporite facies

Thrust boundary (red) between Carpathian nappes ("outer flysch") and foreland basin (yellow in map inset) in south-central Poland; predominant evaporite facies indicated in the foredeep to the north of the frontal thrust, with the location of the Wieliczka and Bochnia salt mines indicated; modified from Krzywiec et al. (2014), itself adapted from Bukowski (2011)

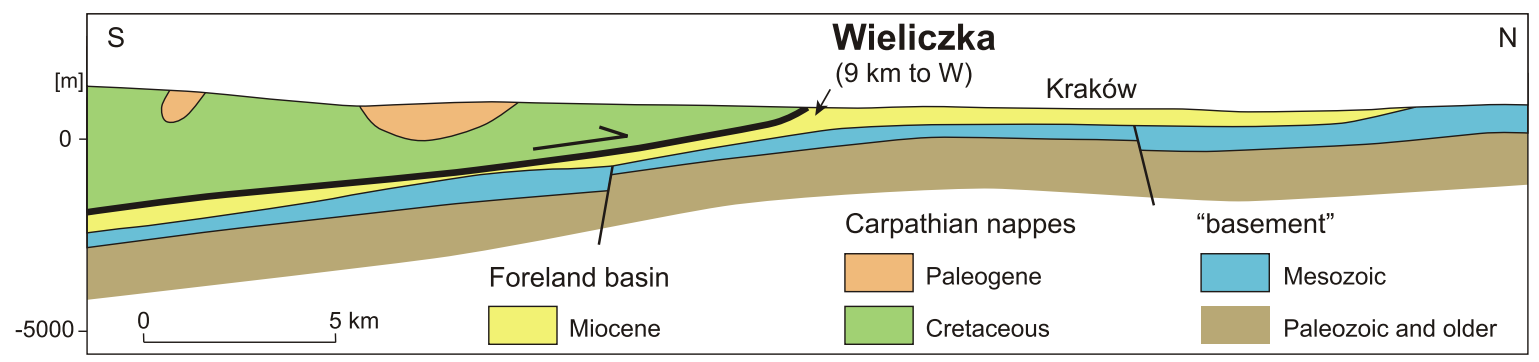

Fig. 3. Simplified cross-section across the frontal Carpathian thrust

Section shows the Carpathian nappes (without internal details) thrust over the Miocene foreland basin, which sits unconformably above Mesozoic and older "basement"; the Wieliczka salt mine is located along-strike directly in front of the exposed thrust front; simplified from ytko et al. (1989), location indicated on Figure 2

and 3), where it comprises part of the Zgłobice Unit of deformed foredeep strata. Although this unit has been interpreted as a gravity-driven nappe (Połtowicz, 1977, 2004), it is envisioned by most as north-directed thrusting due to compression (e.g., Tołwiński, 1956; Poborski and Skoczylas-Ciszewska, 1963). Following a suggestion by Jones (1997), however, seismic data were used to interpret the Zgłobice Unit as a triangle zone in areas to the east of the Bochnia salt mine (Krzywiec et al., 2004, 2014). Similarly, it was proposed by Krzywiec and Vergés (2007) that the Wieliczka salt mine occupies the core of a triangle zone bounded by the north-vergent frontal Carpathian thrust, a basal thrust, and a south-vergent backthrust to the north of the mine (Fig. 4).

\section{STRATIGRAPHY}

Widespread evaporites were deposited in large parts of the central Paratethys during the BSC. The Badenian was defined as a regional stage of the Middle Miocene in the central Paratethys by Papp et al. (1978). During the BSC, there was widespread halite and gypsum deposition in the Carpathian Foredeep, the Transylvanian, Transcarpathian, and EastSlovakian basins (Peryt, 2006), and the area of the Mid-Hungarian shear zone (Báldi et al., 2017). Dating of interbedded tuffs shows that the onset of evaporite deposition was at 13.81 $\pm 0.08 \mathrm{Ma}$ (de Leeuw et al., 2010; Bukowski et al., 2010) and 


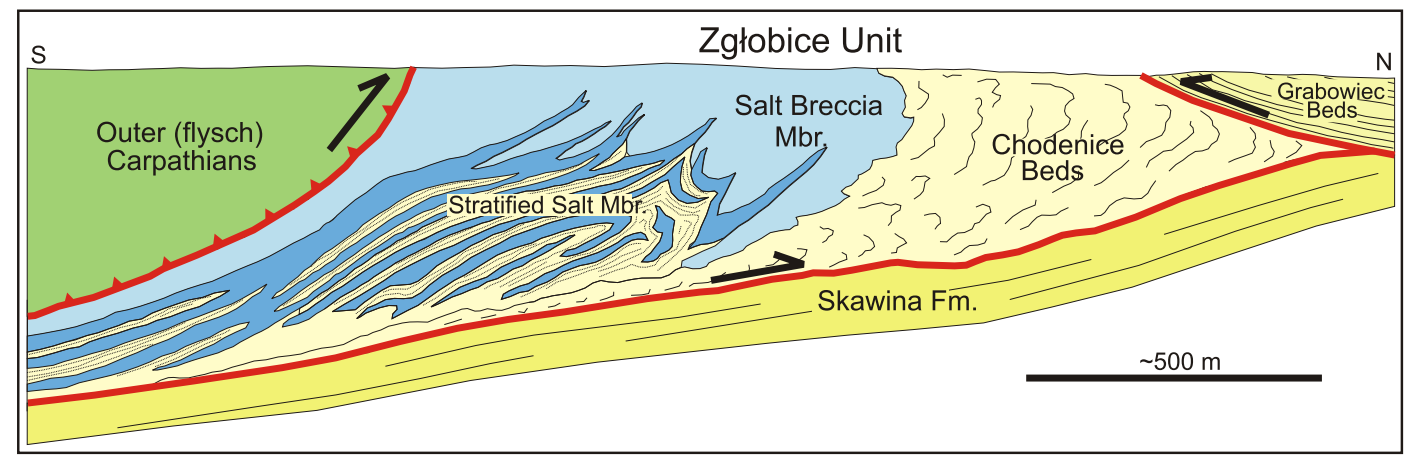

Fig. 4. Wieliczka area within the Zgłobice triangle zone

Interpretation in which the Zgłobice Unit, including the area of the Wieliczka salt mine, is a triangle zone bounded by three detachments (red lines) just north of the frontal Carpathian thrust; modified from Krzywiec and Vergés (2007), itself after a cross-section by Tołwiński (1956)

cessation occurred prior to $13.32 \pm 0.07 \mathrm{Ma}$ (de Leeuw et al., 2018). Thus, deposition spanned a maximum of 0.5 My during the Early Serravalian (Middle Miocene). The LES is bounded below by older Middle Miocene siliciclastics of the Skawina Fm. (predominantly claystones at Wieliczka) and above by younger middle Miocene siliciclastics of the Chodenice Beds, part of the Machów Formation (Fig. 5).

The Wieliczka Formation refers to the halite-rich areas of the Middle Miocene evaporites; where halite is absent or minimal at the margins of the basin and on topographic highs, the equivalent anhydrite-dominated evaporites are named the Krzy anowice Formation (Alexandrowicz et al., 1982; Garlicki, 1994). The LES of the Wieliczka Formation encountered in the mine is illustrated in Figure 5 and described below (from Wiewiórka, 1979, 1988; Garlicki, 1979; Ślączka and Kolasa, 1997; Bukowski, 1997; Wiewiórka et al., 2008; Gonera et al., 2012; Burliga et al., 2018; Bukowski et al., 2019). The thicknesses used are primarily from Wiewiórka (1988) but are known to vary regionally and even within the mine.

Above a basal anhydrite with minor mudstone is the Oldest Salt with thin intercalations of claystone, siltstone, and sandstone, although this unit is relatively poorly known. This is overlain by a layer variously called the Sub-salt Sandstone or Mid-salt Sandstone (although it locally includes conglomerate), and then an unnamed sequence of anhydrite-bearing claystone, minor siltstone and sandstone, and rare halite. Because this entire section of predominantly siliciclastic rocks is bounded above and below by thicker halite-dominant layers (Bukowski, 1997), we refer to it informally here as the Intrasalt Clastic Unit. Above is the Green Stratified Salt, consisting of four halite beds separated by thin sequences of siltstone, anhydritic claystone, and anhydrite. The lowest of these four units (Green Stratified Salt IV) is at least partly a breccia comprising claystone and blocks of the Oldest Salt (Wiewiórka, 1974; Brudnik et al., 2000; Wiewiórka et al., 2008). Above the Green Stratified Salt are the Shaft Salt, lower Spiza Salt, and upper Spiza Salt, which are likewise separated by anhydritic claystones, with the upper Spiza Salt having thin layers of sandstone and salty conglomerate near its top. All layers described above are part of the Stratified Salt Mbr. (SSM). Conformably above the SSM is the Salt Breccia Mbr., also termed the Boulder Salt, a thick succession of claystones and salty claystones with blocks of different types of halite up to $>100 \mathrm{~m}$ across.
Detailed studies (Garlicki, 1979; Kolasa and Ślaczka, 1985a, b; Ślaczka and Kolasa, 1997; Gonera et al., 2012) demonstrate that although some of the halite layers are original precipitates, many represent redeposited salt. The remobilized evaporites and interbedded siliciclastics represent deposition by a combination of debris flows, turbidity currents, fluidized flow, storm reworking, and slumping (Połtowicz, 1977; Kolasa and Ślączka, 1985a, b; Ślączka and Kolasa, 1997; Bukowski, 1997, 2011; Gonera et al., 2012). Similar interpretations have been made in other parts of the Carpathian Foredeep salt basins (e.g., Peryt and Kovalevich, 1997). Even the Salt Breccia Mbr., with its large olistostromes of halite, is interpreted as a mega-debrite with a depositional rather than tectonic origin (although there are dissenting interpretations, e.g., Garlicki, 1979; Tarka et al., 1988; Tarka, 1992). The reported observations suggest there was a significant slope to the depositional profile during the BSC. This was probably related to advancement of the frontal Carpathian nappe as indicated by the greater prevalence and thickness of coarser-grained siliciclastics, including clasts of Carpathian flysch, in the southern part of the evaporite basin (Kolasa and Ślączka, 1985a; Ślączka and Kolasa, 1997).

The Wieliczka LES forms a multilayer comprising layers with different compositions, rheologies, and thicknesses. Thus, there are significant variations in relative strength that are indicated in Figure 5. Pure halite is the weakest rock and coarse-grained siliciclastics form the strongest layers (see e.g., Urai et al., 1986; Weijermars et al., 1993; Rowan et al., 2019). Other beds are expected to have intermediate strength that differs depending on the relative proportions of claystone, anhydrite, and other lithologies, but the details of this are unknown. Thus, the absolute and relative strengths depicted in Figure 5 are schematic. In any case, the key horizons that delineate units of significantly different strength and thus mechanical behaviour are interpreted to be: the base of the Oldest Salt, the top of the Oldest Salt, the base of the Green Stratified Salt, and the top of the Spiza Salt. The resulting mechanical stratigraphy is expected to vary spatially as the thicknesses and compositions of individual layers change.

\section{STRUCTURAL GEOMETRY}

The large-scale structure of the Wieliczka area comprises a series of asymmetric folds and/or thrusts vergent toward the 


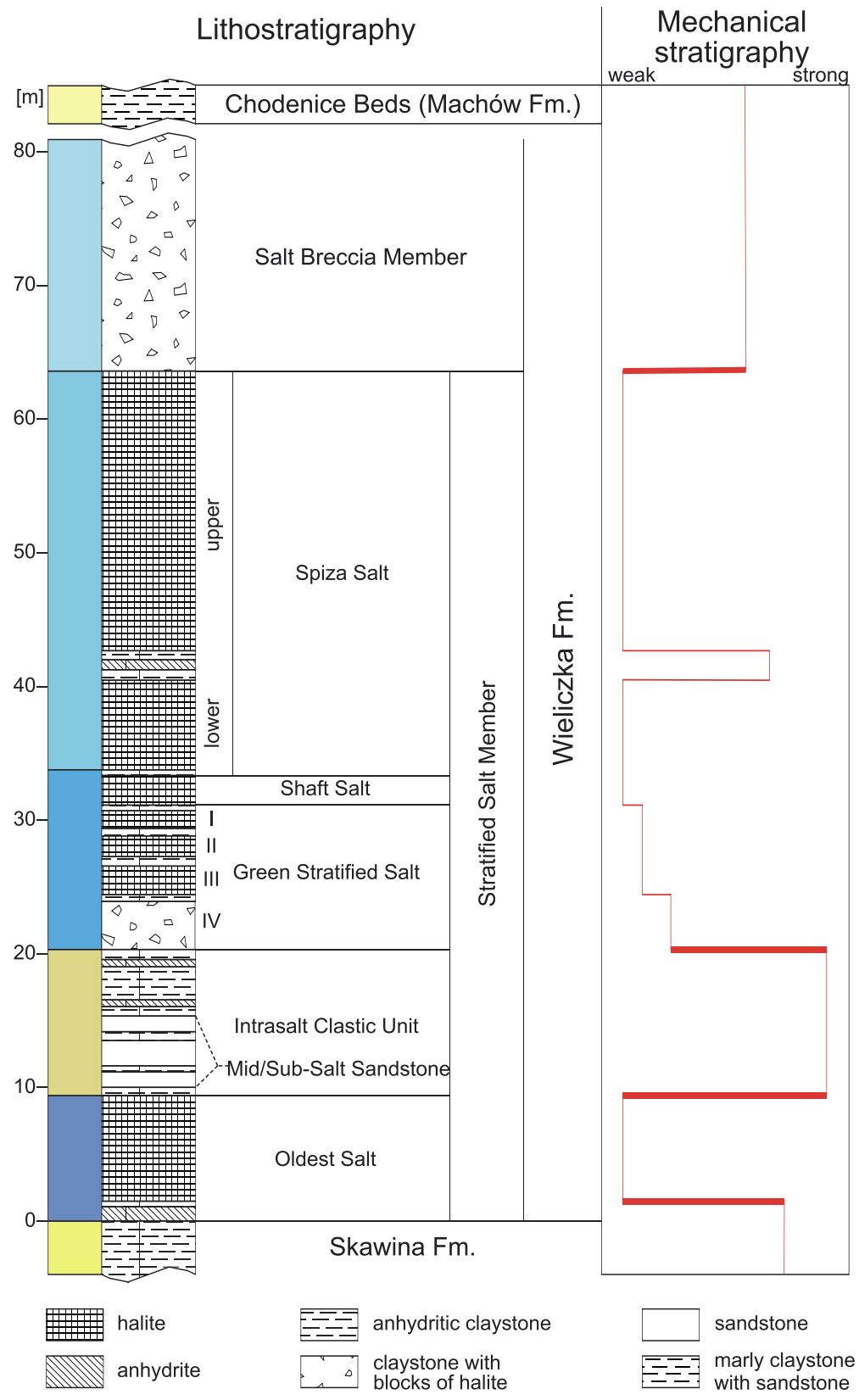

Fig. 5. Stratigraphy of the Wieliczka area

Lithostratigraphy and thicknesses from Wiewiórka (1988); nomenclature within the salt sequence is that established for the Wieliczka area, with the exception of the Intrasalt Clastic Unit, which is an informal name that includes the Mid/Sub-salt Sandstone; blue colours for the Green Stratified Salt through Salt Breccia Member are those used in Fig. 6, whereas other colours are those used in Fig. 12; mechanical stratigraphy shows the interpreted approximate relative strength of the different layers, with the thick red lines marking the key mechanical boundaries

foreland in the north (Figs. 4 and 6). Most published cross-sections show variations on this theme (Pusch, 1824; Hrdina and Hrdina, 1842; Tołwiński, 1956; Gaweł, 1962; Poborski and Skoczylas-Ciszewska, 1963; Tarka, 1992; Burliga et al., 2018). Serial sections by Gaweł (1962) show that backlimbs are subhorizontal to gently south-dipping (maximum $\sim 30^{\circ}$ ), whereas forelimbs are generally shorter, slightly steeper, and overturned (Fig. 6B). Having said that, it is unclear how much is just folding and how much is thrust repetition, something we return to be- low. Also, there are examples of superposed folding, where the tight structures are refolded in larger-scale, open, upright folds (Fig. 6B). The folds trend E-W to ESE-WNW and the entire complex generally plunges to the $\mathrm{W}$.

Researchers have noted for centuries the small-scale structures, both ductile and brittle, within the Wieliczka salt mine (e.g., Fig. 1A, B). Folding occurs at a variety of scales (metric to millimetric) in both the weaker halites and stronger siliciclastics, and includes largely harmonic folds, disharmonic and polyharmonic folds, and superposed folds; brittle structures include thrust faults, extensional faults, boudinage, joints, and veins (e.g., Schober, 1750; Pusch, 1824; Gaweł, 1962; Kolasa and Ślączka, 1985b; Tarka et al., 1988; Tarka, 1992; Ślączka and Kolasa, 1997; Cyran, 2008; Burliga et al., 2018). It is often assumed that, since the trends and vengence of the small-scale structures are similar to those of the large-scale structure, the origin is also the orogenic north-vergent thrusting. However, the recognition of clear sedimentary reworking and slumping (Kolasa and Ślączka, 1985a, b; Ślączka and Kolasa, 1997; Gonera et al., 2012) suggests that at least some of the small-scale structures might represent soft-sediment deformation. Burliga et al. (2018) proposed that early synsedimentary structures, both extensional and contractional, were overprinted by the tectonic deformation. But they also warned that the superposition and similar orientations ( $\mathrm{N}$-dipping depositional slope and $\mathrm{N}$-directed thrusting) make it difficult to differentiate between the different origins and processes.

\section{OBSERVATIONS}

Because this paper addresses both the largescale and small-scale structures within the Wieliczka salt mine, our dataset likewise is at two scales. For the overall geometry of the folded/thrusted multilayer, we did no mapping or measuring ourselves. Instead, we relied on published crosssections and maps, primarily those of Gaweł (1962), who produced the most detailed illustrations of the three-dimensional geometry (Fig. 6) through a series of eight maps at the different corridor levels (roughly 20-40 m apart) and twelve cross-sections with a spacing of between 150 and $650 \mathrm{~m}$. Note that the focus of the mapping was on the economically most valuable salt levels, so that the older portions of the sequence are not as well-defined. In any case, we evaluated the geometries in these and other published sections from the perspective of the mechanical stratigraphy of the multilayer shown in Figure 5.

For the analysis of the small-scale deformation, we studied only a small area within the Spiza Salt on Level II Lower in and around the Franciszek corridors (Fig. 6). The position is on the backlimb of one of the major folds, although there are also meso-scale folds within the area. We examined meso- to small-scale folds, thrust faults, extensional faults, and boudins, but did not include joints, veins, or enterolithic folds. Because both extensional and contractional structures overlap spatially (e.g., folds of boudinaged layers), we focused on determining 


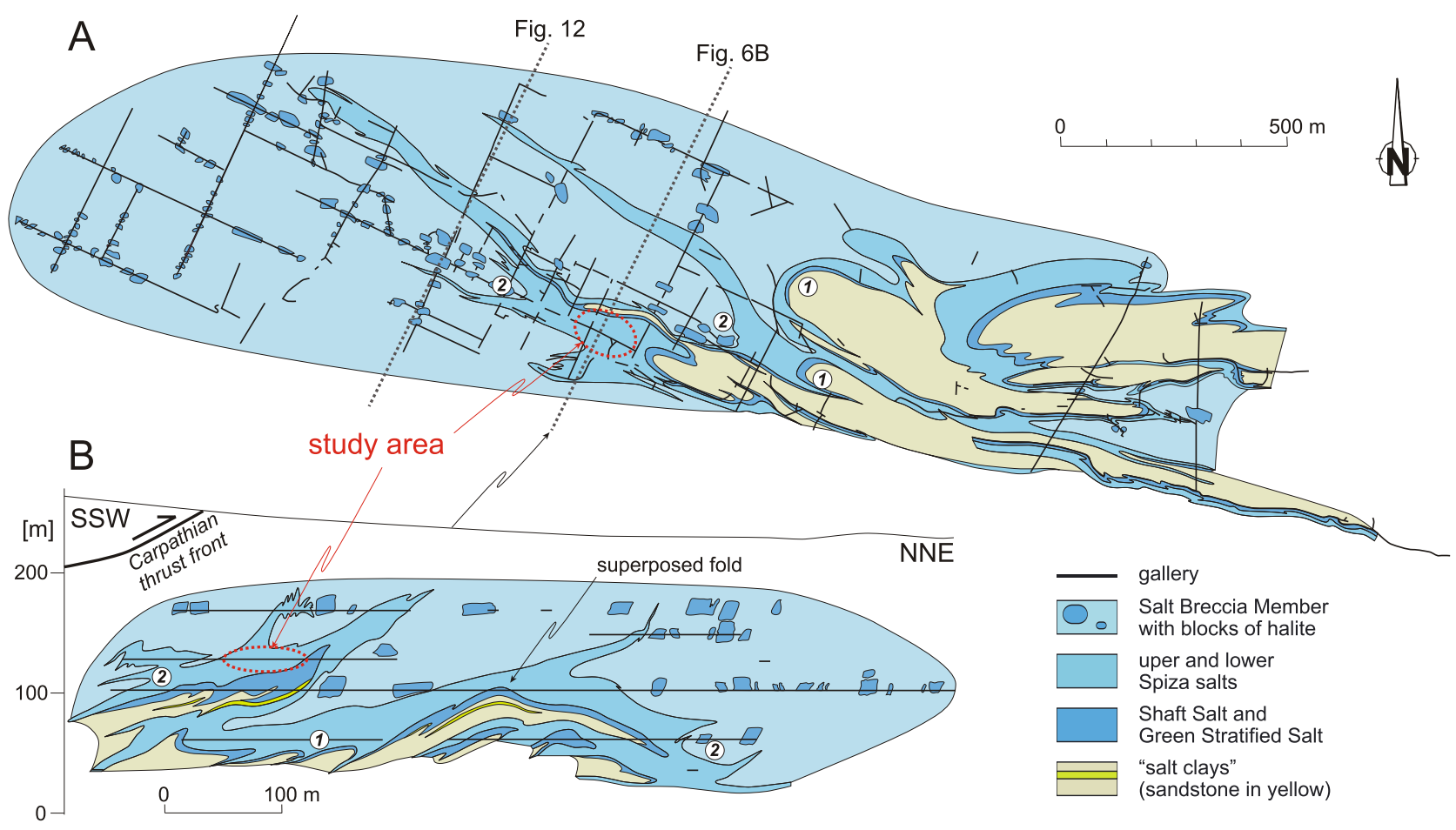

Fig. 6. Map and cross-section showing location of study area

A - map of Wieliczka mine Level II Lower, located at $133.5 \mathrm{~m}$ a.s.I. ( 120 m b.g.I.); B - cross-section through study area, located in and near the Franciszek corridors; both figures modified from Gaweł (1962); "salt clays" is equivalent to the Intrasalt Clastic Unit used in this study; numbers in circles indicate locations discussed in the text

the relative timing where possible. Orientations were measured anywhere within the study area where features observed on a corridor wall (two-dimensional cut) could be traced onto the roof so that the three-dimensional orientations could be determined. This inherent limitation, combined with the small size of the study area, resulted in relatively few measurements, mostly of larger structures.

\section{CONTRACTIONAL STRUCTURES}

As cited above, the large-scale fold geometries are characterized by long, gently south-dipping backlimbs and shorter, steeper to overturned forelimbs (Fig. 6B). Existing interpretations show that the geometries are cuspate-lobate, typical of folds developed in multilayers with low to moderate competency contrasts (see Ramsay, 1982; Ramsay and Huber, 1987). Specifically, the Intrasalt Clastic Unit usually forms lobate anticlines while the overlying salt layers form pointed, cuspate synclines (Fig. 6: locations 1); conversely, although not as clear and systematic, the Salt Breccia Mbr. often forms tight but lobate synclines and the underlying Spiza Salt sticks up as pointed anticlines into the breccia (Fig. 6: locations 2). The overall pattern is diagnostic of two more competent layers encasing a less competent unit. In this case, the weaker salt sequence (Spiza, Shaft, and Green Stratified salts) is surrounded by the stronger Salt Breccia Mbr. and Intrasalt Clastic Unit (Fig. 5), a multilayer competency contrast that strongly influenced the fold geometries.

Meso-scale folds have a similar form to the large-scale structures, with elongate, gently dipping backlimbs and shorter, steeper forelimbs (Fig. 7A). The forelimbs may dip to the north (Fig. 7A) or be vertical to overturned (Fig. 7B), and they may be thrusted (Fig. 8B) or, more rarely, sheared and thinned dramatically (Fig. 7C). Folding ranges from harmonic to disharmonic to polyharmonic, with thinner sequences of strong layers having shorter-wavelength folds (Figs. 7A and 8B, C). Hinge zones and forelimbs are often thickened relative to backlimbs and characterized by more intense deformation of the strong layers (Figs. 7B and 8C). Halite accommodates the different geometries between sequences of stacked strong layers.

Fold limbs and hinge zones contain smaller-scale contractional structures (Figs. 7 and 8). These typically involve boudinaged layers, but we focus here on the contraction and return to the boudinage below. The small-scale deformation includes harmonic to disharmonic folds, thrusted layers, and boudins, and more chaotic patterns in forelimbs and hinge zones. The style is perhaps best illustrated in Figure 7C: in some places, the slightly thicker, light grey layer and the relatively thinner, darker-grey layer are gently folded together; but in most parts of the structure, they behave more independently, each with its own series of thrusts and folds. Halite fills the intervening spaces created by the disharmonic deformation.

Whereas some parts of the study area contain meso- to small-scale structures, others appear to be unaffected. Halites may shorten locally by pure-shear and associated simple thickening, and thus appear undeformed, but the variable amount of shortening also appears to be the case for the anhydritic claystones and the sandstones. For example, in the transect of Figure $8 \mathrm{~A}$, there is a panel of apparently undeformed strata between the detailed photos of Figure 8B, D. However, this is misleading: the upper part of the sequence forms the thrust hanging wall in Figure 8B, and the lowest part is folded right at the top of the corridor wall (Fig. 8D, upper right). Although larger areas of exposure would allow a more accurate analysis, it is unclear from the 

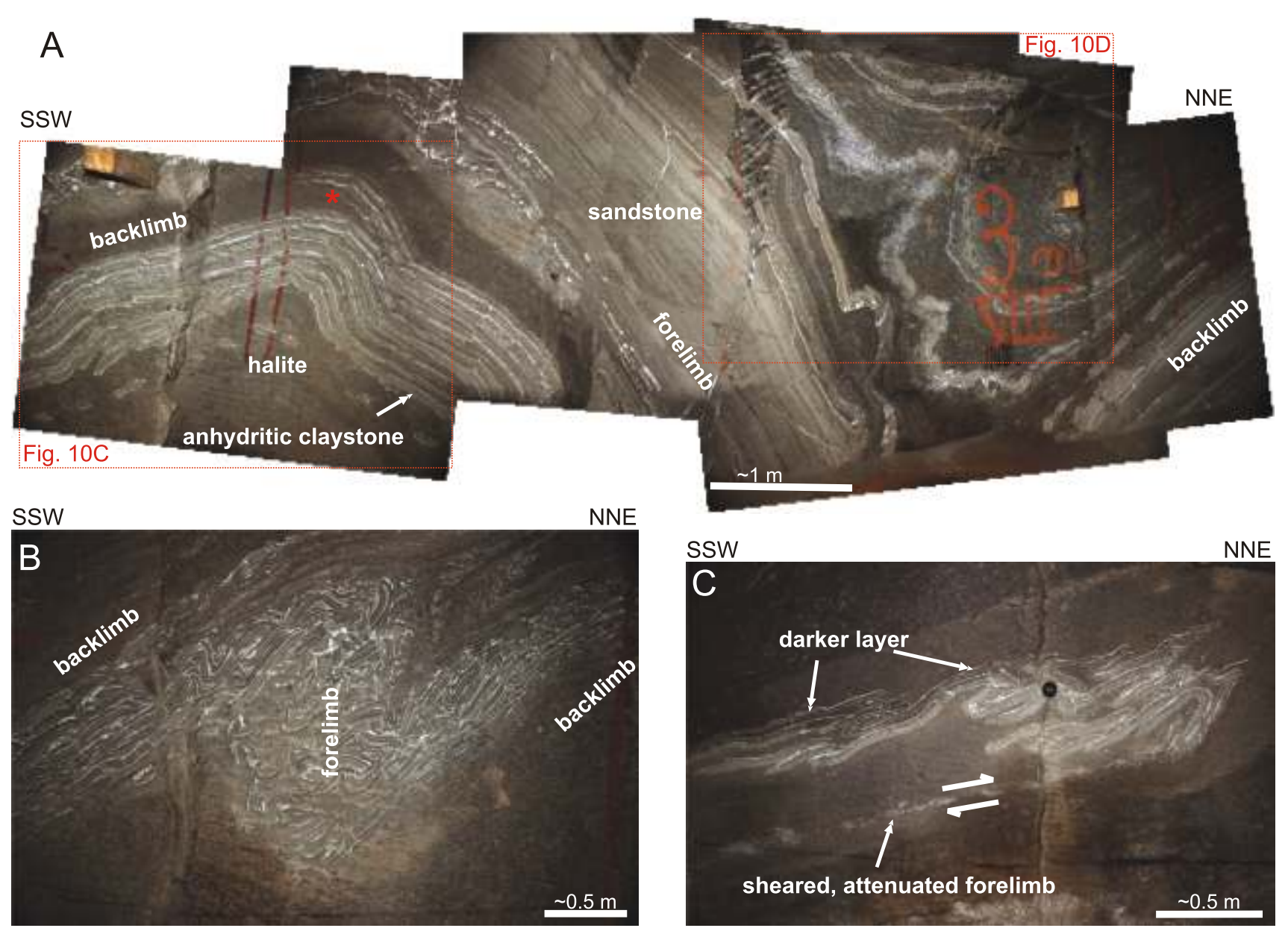

Fig. 7. Contractional structures in the Spiza Salt shown by boudinaged stronger siliciclastic layers (light grey) interbedded with halite (dark grey)

A - photo mosaic showing steep forelimb between two backlimbs, with smaller-scale disharmonic folds in synclinal hinge zone; dashed red boxes show the locations of other figures and the red asterisk indicates a problem in the photo stitching; $\mathbf{B}$ - asymmetric fold pair with short, thickened forelimb comprising contorted boudins; C - isoclinal fold of two layers of anhydritic claystone (one light, one dark), with the lower, overturned limb stretched and attenuated by shear (white arrows)

limited exposures whether individual sequences have the same or different amounts of internal shortening.

Within the small study area, the meso-scale folds recorded by the strong layers are remarkably cylindrical considering they are in evaporite-rich strata. The attitudes of bedding, thrust faults, axial planes, and fold axes all indicate $\mathrm{N}-\mathrm{S}$ directed shortening with subhorizontal fold axes (Fig. 9A). This is compatible with the large-scale tectonic shortening direction recorded by the generally E-W striking thrusts and folds of the outer Carpathian nappes (Fig. 2), but slightly oblique to the WNW-ESE striking large-scale folds of the Wieliczka salt mine (Fig. 6A).

\section{EXTENSIONAL STRUCTURES}

As already noted and as shown in Figures 7 and 8, the sandstones and anhydritic claystones, although folded, are also characterized by extensional faults and boudins. Generally, thicker strong packages tend to be faulted and thinner layers tend to be boudinaged (Fig. 10A, B). Moreover, single thinner layers encased in halite may have significant boudinage (Fig. 10A, C: locations 1) while thicker sequences of strong lay- ers with thin intervening halite have less extensional deformation (locations 2). Different layers, even when very close to each other, show unequal amounts of extension at the scale of observation.

A key aspect of the geometry is that layers are extended regardless of structural position on the contractional structures. Boudins and extensional faults are practically ubiquitous on gently south-dipping backlimbs (Figs. 7, 8 and 10) but also occur on forelimbs (Fig. 10C, D). It is difficult to judge the relative amounts of extension in these two structural positions because many of the boudins also display unquantifiable amounts of contraction; for example, the original spacing between the two boudins that are now overlapped in Figure 10F is unknown. Moreover, there are many pieces of layers that are thrust over each other (Fig. 10C, D, F), but it is not always clear whether these were originally boudins or were continuous prior to thrusting.

Because most extensional structures are confined to individual layers or are boudins, there are few examples where they can be traced onto the roof so that the three-dimensional orientation can be determined. Nevertheless, measurements of five slightly larger faults offsetting thicker strong packages (e.g., those in Fig. 10B) yield trends that are distinct from those of the 

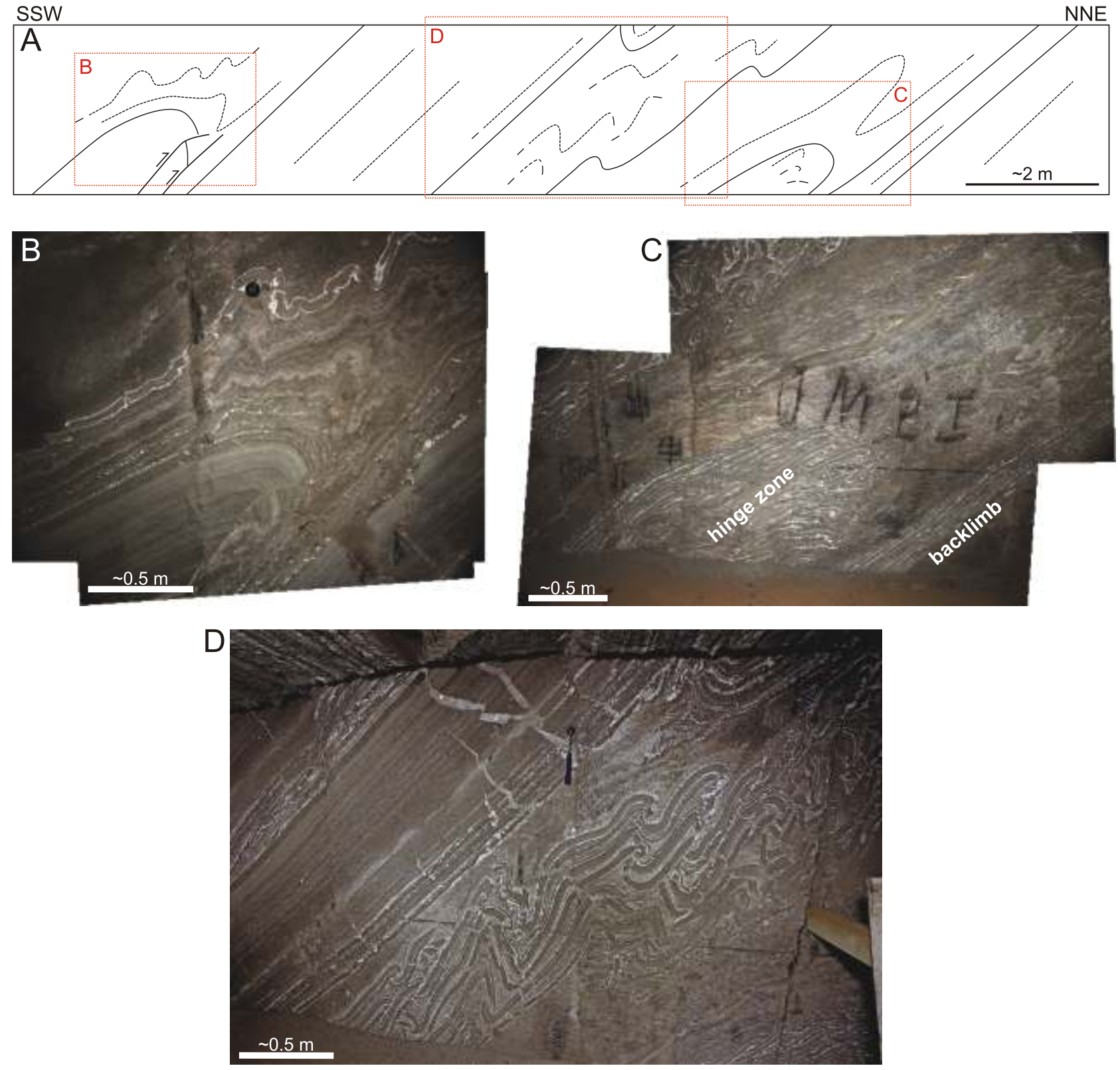

Fig. 8. Variations in structural style along a transect in the Spiza Salt

A - sketch of geometries along a roughly $16 \mathrm{~m}$ transect on the backlimb of a larger fold; dashed red boxes indicate photos in other parts of figure; B - thrusted thicker strong layer with disharmonic smaller-scale folds in overlying thinner-bedded units (location and interpretation shown in A); $\mathbf{C}$ - thickened anticlinal hinge zone of boudinaged anhydritic claystones above equivalent, thinner backlimb (location and interpretation shown in A); $\mathbf{D}$ - sequence of anhydritic claystones, each boudinaged, with harmonic to disharmonic thrusts and folds within gently folded meso-scale limb with disharmonic fold above (location shown in A)

contractional structures (Fig. 9B). In one area, two faults strike NW-SE, and in another, three faults strike closer to N-S. Although few in number, these data suggest extension in a direction moderately to highly oblique to that of shortening. This is true regardless of whether the extension happened after contraction (solid lines) or prior to shortening (dashed lines).

\section{INTERPRETATION}

In the following sections, we offer our preliminary interpretation of the intrasalt deformation at the Wieliczka salt mine. First, we offer a model for the geometry and development of the large-scale structure using the mechanical stratigraphy and a context of overthrust shear between the basal salt detachment and the overriding Carpathian thrust sheet. Second, we evaluate the relative timing of meso- to small-scale extensional and contractional structures and propose a model that explains our observations.

\section{LARGE-SCALE GEOMETRY}

We offer below a complete cross-section through the Wieliczka salt mine that attempts to: 


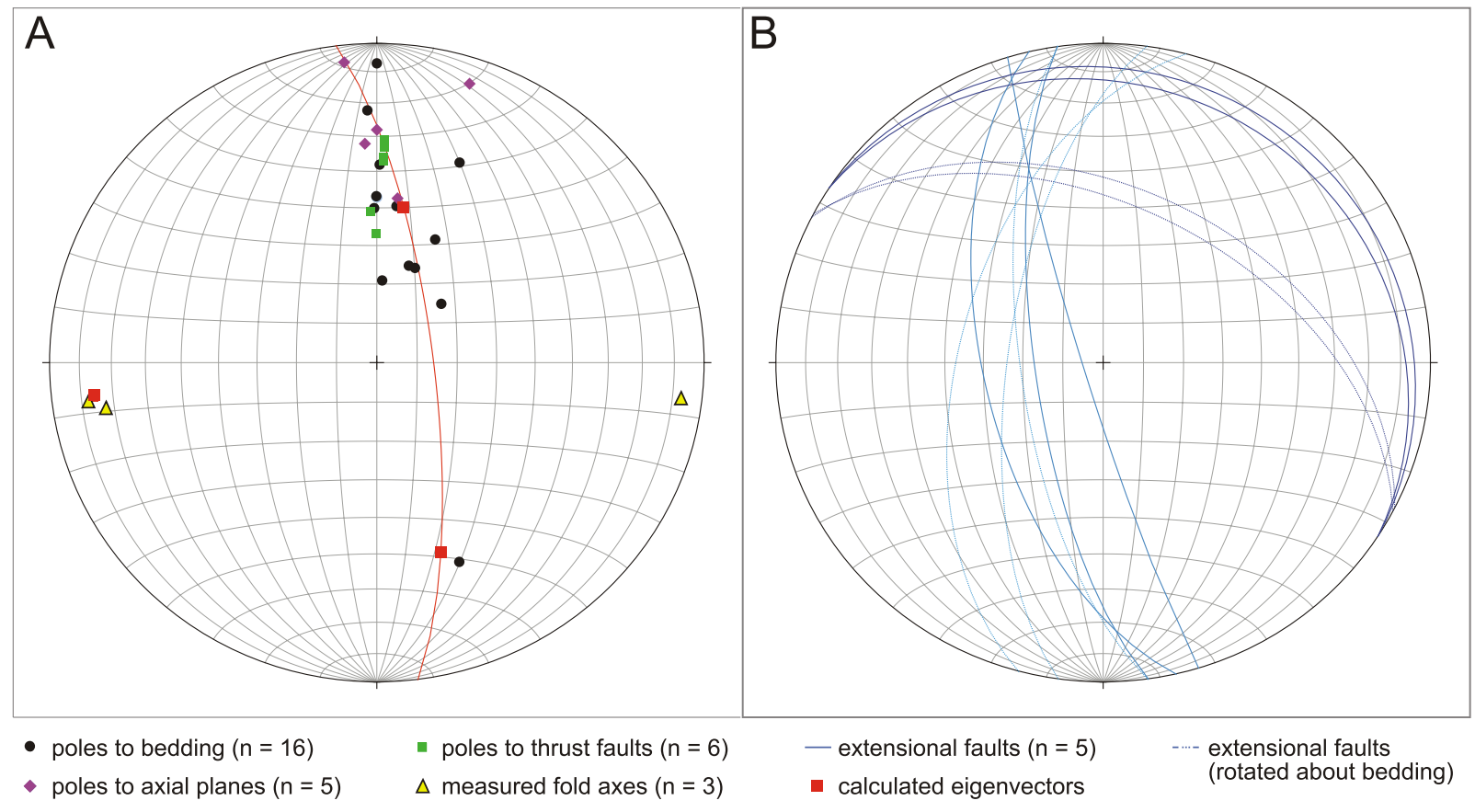

Fig. 9. Lower-hemisphere, equal-area stereonet plots of small-scale structures

A - contractional features (folded bedding, thrust faults, axial planes, and fold axes) showing cylindrical nature of folds in the study area; red line is best-fit great circle to poles to bedding, with calculated fold axis indicated by the red square perpendicular to it; $\mathbf{B}$ - extensional faults shown with both their current attitudes and the attitudes after unfolding the strata to horizontal; in the legend, "n" - number of data points

- honour the mechanical stratigraphy and resultant structural styles;

- provide an explanation for the observed geometries of the large-scale folds;

- fill the space in the core of the large-scale structure, i.e., between the mine corridors and the deep detachment.

To do this, we first address key aspects of the mechanical stratigraphy, then introduce the process of deformation in overthrust shear, and finally present our model cross-section.

\section{MECHANICAL STRATIGRAPHY}

As shown in Figure 5, the Wieliczka Formation forms a multilayer with a distinct mechanical stratigraphy. We divide the LES into four sequences of contrasting rheologies:

- a thin basal halite-dominated layer that is weak (Oldest Salt);

- a thin beam of relatively competent, mostly siliciclastic rocks (Intrasalt Clastic Unit);

- a thicker halite-dominated package that is weak but internally variable due to the complex interbedding with thin claystones and other stronger rocks (Green Stratified, Shaft, and Spiza salts);

- a thick unit of uncertain but probable intermediate strength (Salt Breccia Mbr.).

Thus, the Oldest Salt is likely to be the basal detachment and the main salt sequences should decouple deformation in the bounding stronger units.
The thicknesses are critical in several ways. First, the style of salt-detached shortening depends in large part on the thickness and frictional character of the décollement layer (Davis and Engelder, 1985; Stewart, 1999). Thick salt leads to more symmetric deformation dominated by detachment folds, with the salt filling anticlinal cores. In contrast, thin or welded salt, due to its more frictional character, leads to thrust-dominated deformation that is vergent toward the foreland. Whether such thrusted structures initiated as detachment folds, with the faults breaking out through one of the fold limbs (break-thrust folds of Willis, 1893; Fischer et al., 1992), or as source-fed thrusts (Hudec and Jackson, 2006), salt would have been carried up in the hanging walls to shallower levels (Rowan, 2020). Second, the thickness of a competent layer is the primary factor in controlling the wavelength of structures, with thicker supra- or intrasalt strong layers forming longer-wavelength folds or more widely spaced thrusts, and thinner layers generating short-wavelength structures (Ramberg, 1960; Biot, 1961). In short, and by combining these factors, the Intrasalt Clastic Unit is expected to have relatively closely spaced thrusts because both it and the underlying salt detachment are thin (Fig. 5), as seen in the cross-section by Poborski and Skoczylas-Ciszewska (1963). The Salt Breccia Mbr., however, should form longer-wavelength folds due to the thickness of both it and the main salt sequence beneath it (e.g., Tołwiński, 1956; Garlicki, 1968).

There are, of course, complicating factors that influence the structural style. Other variables such as strain rate can play a role, and both rheologies and thicknesses can vary from hinterland to foreland and along strike. For example, the fans of both the intra-Spiza siliciclastic layer and the Intrasalt Clastic Unit are 

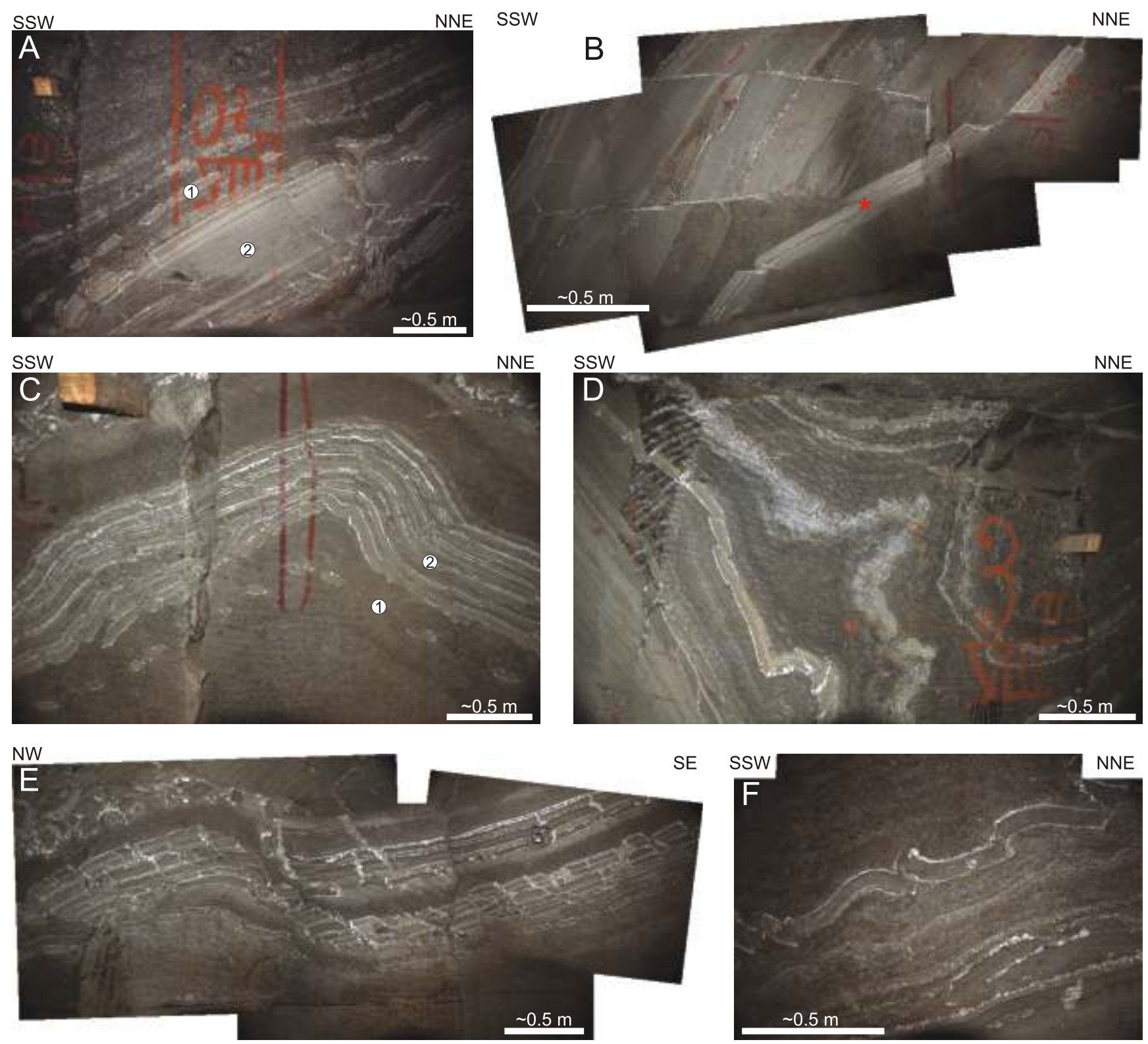

Fig. 10. Small-scale extensional structures within the Spiza Salt

A - strong siliciclastic layers with different styles (extensional faults and boudins) and magnitudes of extension on backlimb of larger fold; B photo mosaic of decoupled extension in thick and thin strong layers (red asterisk indicates an apparent thrust that is an artifact of the photo stitching); C - simple anticline with variably boudinaged anhydritic claystones on both limbs; note large amount of extension of deepest, more isolated layer (location shown in Fig. 7A); D - disharmonically folded layers of boudins on north-dipping forelimb of meso-scale fold, with boudins sometimes thrusted or overlapping (location shown in Fig. 7A); $\mathbf{E}$ - photo mosaic showing oblique cut through gently folded strong layers with extensional faults and boudins; $\mathbf{F}$ - photo mosaic of overlapping and folded boudins on backlimb of meso-scale anticline; numbers in circles indicate features discussed in the text

thickest in the centre of the Wieliczka mine (Ślaczka and Kolasa, 1997; Bukowski, 1997; Gonera et al., 2012). In contrast, the debrites of the Salt Breccia Member and Green Stratified Salt IV both thicken to the east (e.g., Szybist, 1975; Gonera et al., 2012).

\section{OVERTHRUST SHEAR}

The fold geometries depicted in existing published crosssections of the Wieliczka area are reminiscent of those observed in fold-and-thrust belts such as the Variscides of SW England, the Helvetic Nappes of the Swiss Alps, and the South- ern Appalachians of the USA (Sanderson, 1979; Ramsay et al., 1983; Gibson and Gray, 1985). These settings are characterized by cascading sets of asymmetric folds with a moderately dipping or even curved fold envelope, with the hinterland folds perched above and behind more frontal, deeper, and more recumbent structures (cf. Fig. 6B). They are interpreted to form by overthrust shear, in which the folds develop between two overlapping thrust detachments (Ghosh, 1966; Manz and Wickham, 1978; Sanderson, 1979; Casey and Huggenberger, 1985; Dietrich and Casey, 1989; Rowan and Kligfield, 1992). We know of no other process that generates this particular structural style. 

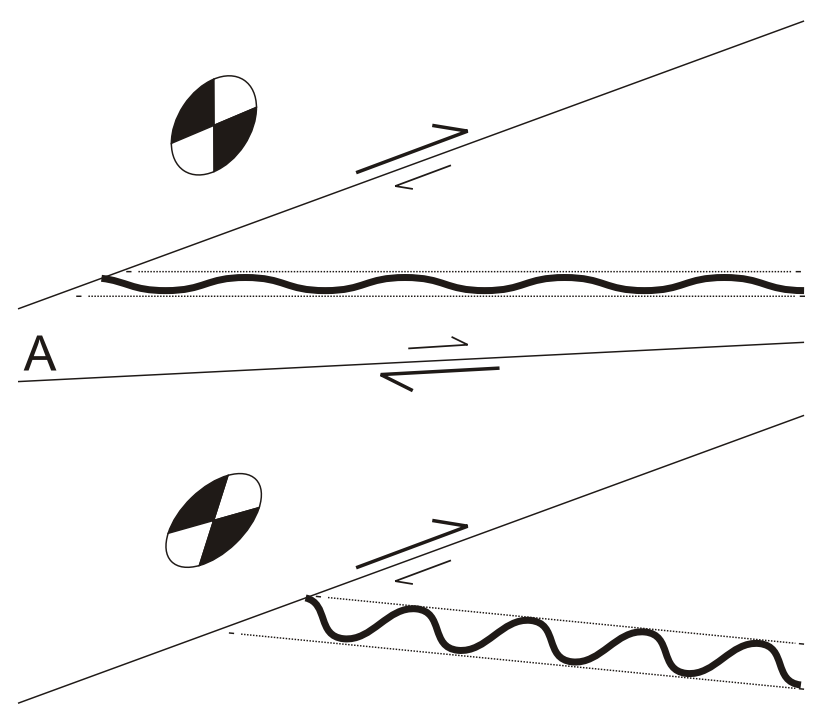

B
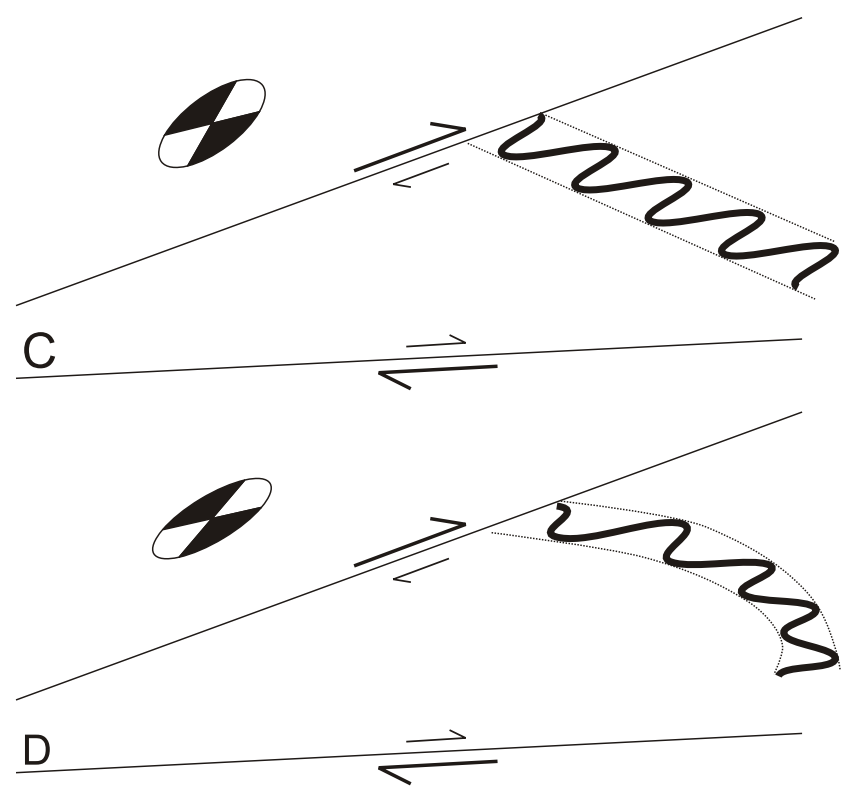

Fig. 11. Fold development during overthrust shear between diverging thrusts

A - originally horizontal bed forms symmetric buckle folds (thick line) and horizontal fold envelope (thin-dashed lines); B - folds amplify and begin to develop asymmetry as fold envelope rotates; $\mathbf{C}$ asymmetry and fold-envelope dip both increase as forelimbs become overturned; D - curved fold envelope and deeper recumbent folds if simple shear is concentrated in lower part of wedge; movement relative to basal detachment not shown; ellipse shows approximate finite strain ellipse for each stage, with black and white indicating contractional and extensional fields, respectively; adapted from Sanderson (1979) and Rowan and Kligfield (1992)

In overthrust shear, the bounding thrusts may be parallel or divergent toward the foreland. Bedding originally oriented at an angle to the detachments first forms symmetric buckle folds (Fig. 11A). With increasing simple shear between the two thrusts, the folds rotate and become asymmetric, primarily by rotation of the forelimbs and axial surfaces and less by rotation of the backlimbs (Fig. 11B). Eventually, the forelimbs rotate past vertical to overturned (Fig. 11C). The fold envelope (the surface connecting anticlinal or synclinal hinges) rotates from subhorizontal to ever steeper dips toward the foreland. If simple shear is unevenly distributed, as is common, the fold envelope develops curvature (Fig. 11D). Note that there is no squeezing of the wedge between the thrusts; instead, there is slip on both thrusts and shear of the rocks in between.

The finite strain ellipse in overthrust shear is oriented obliquely to the bounding thrusts and rotates over time to closer to the dip of the detachments (Fig. 11). This has several implications for smaller-scale deformation. First, backlimbs are generally aligned in the extension direction and thus may lengthen, producing extensional structures even in an overall contractional setting. Forelimbs have a more complex history: when dipping toward the foreland (Fig. 11A, B), they are in the contractional domain and thus may shorten and thicken; but as they rotate to overturned orientations (Fig. 11C, D), they eventually enter the extensional domain and thus may develop extensional features that overprint earlier contractional structures.

MODEL

To display our proposed cross-sectional geometry, we use cross-section 8 of Gaweł (1962), located 400 m west of the section in Figure 6B, as a framework for several reasons. First, it is in the central area where there are corridors located along or near the line at nine levels, so that the geometry is relatively well constrained. Second, there are other sections by Gaweł located $\sim 170 \mathrm{~m}$ to either side so that along-strike variations in geometry can be evaluated. Third, we have thickness trends in the central part of this area for both the Intrasalt Clastic Unit (Bukowski, 1997) and the Green Stratified Salt (Gonera et al., 2012). And fourth, section 8 shows some of the key features of Wieliczka, including the three major shallow folds/thrusts and some of the deeper repeats of section.

We use only the known data along the corridors and information from nearby areas as depicted on Gawel's sections and maps. However, comparison of Gawel's section 12, in the eastern part of the mine, with that of Brudnik et al. (2000) in the same area, shows some significant differences in interpretation in the deeper parts of the stratigraphy. Specifically, one body of Spiza Salt in Gaweł (1962) was identified as the Green Stratified Salt IV in Brudnik et al. (2000), and several areas of older "salt clays" of Gaweł (1962) were reinterpreted by Brudnik et al. (2000) as the Green Stratified Salt IV with smaller outcrops of the "undersalt" siliciclastics (our Intrasalt Clastic Unit). In addition, according to Gonera et al. (2012), the Oldest Salt is very similar to the upper parts of the Spiza Salt, with which it has been confused. Thus, we have reinterpreted some of the geometries depicted in Gawel's section at the deeper levels and have focused on repeats of sandstone within the "salt clays" in his sections and maps. Moreover, we have lumped together the Spiza, Shaft, and Green Stratified salts to emphasize the primary mechanical stratigraphy described above and shown in Figure 5.

The biggest unknowns are, first, the geometric relationship between the Carpathian nappes and the Wieliczka Formation just south of the mine (corridors have crossed from the Salt Breccia Mbr. into the flysch) and, second, how to fill the space between the deepest mine levels and the basal detachment. The detachment is somewhat constrained by boreholes drilled beneath the western part of the mine, which encountered claystone and anhydrite, presumably of the Krzy anowice Formation (the equivalent to the Wieliczka Formation), and then the presalt Skawina Formation at $\sim 100 \mathrm{~m}$ b.s.l. (from unpub- 
lished mine archives). Since there are no deep data in the area of the cross-section, we consider several conceptual end-member possibilities to fill the space between this detachment and the corridors:

- with deformed Skawina beds, but this would require a deeper detachment beneath the salt;

- with thrusted and/or folded strata of the Intrasalt Clastic Unit;

- with overturned or repeated Green Stratified, Shaft, and Spiza salts and even the Salt Breccia Mbr. Although Skawina beds have been reported from the corridors, these are likely just reworked clasts, just as there are clasts of older parts of the LES and even of Carpathian flysch.

Thus, we opted for a combination of the last two options, namely both repeated/overturned stratified salts and breccia as well as shortened Intrasalt Clastic Unit beds. We emphasize, though, that the depicted geometry beneath the mine corridors is mostly unconstrained and thus schematic.

The large-scale geometry depicted in Figure 12 is most similar to that shown by Poborski and Skoczylas-Ciszewska (1963). We speculate, based on the boreholes that encountered the deep detachment level, that the deformation was localized by an abrupt transition across a basement fault from stratified salts of the Wieliczka Formation to equivalent anhydrites and claystones of the Krzy anowice Formation (Fig. 12), although any such feature is probably located farther south than shown. The overall form of the deformed LES is that of overthrust shear with enhanced shear near the base of the divergent wedge (Fig. 11D). Within the wedge, the structural style is dependent on the mechanical stratigraphy of the multilayer
(Fig. 12). The thin, competent Intrasalt Clastic Unit forms thrust imbricates detached on the equally thin Oldest Salt (Fig. 13). The imbricates form several duplexes at three levels that are thrust into the Green Stratified, Shaft, and Spiza salts, as shown in the deepest corridor levels. Because some of the Oldest Salt is carried up in the hanging walls of the thrusts (Fig. 13), it overrides the younger salts in places and might have been tectonically mixed due to shear accommodating the emplacement, thereby complicating the task of stratigraphic identification of different salt layers. This may have occurred at the Green Stratified Salt IV level, where the thrusts first emerge into the salt overlying the Intrasalt Clastic Unit, or higher in the stratigraphy. In contrast to the thrust-dominated deeper deformation, the thicker Salt Breccia Mbr. forms inclined to recumbent isoclinal anticlines cored by narrow spines of the Spiza Salt. The intervening synclines of the Salt Breccia Mbr. are lobate, extending down into the underlying salt. It is the main salt sequence, comprising the Green Stratified, Shaft, and Spiza salts, that accommodates the very different geometries above and below. It is unclear, however, how much of the salt beneath the duplexes is overturned or right-side-up.

The cross-section (Fig. 12) was drawn so that the amount of shortening is balanced for the top of the thrusted Intrasalt Clastic Unit and the base of the folded Breccia Mbr. Each level has $\sim 2.1 \mathrm{~km}$ of shortening, not including the amount of displacement on the basal detachment. However, it is not unreasonable that some shortening might have been ongoing during deposition of the Wieliczka Formation, so that the deep levels should actually have more shortening. After all, the advancing Carpathian nappes were shedding eroded sediment into the

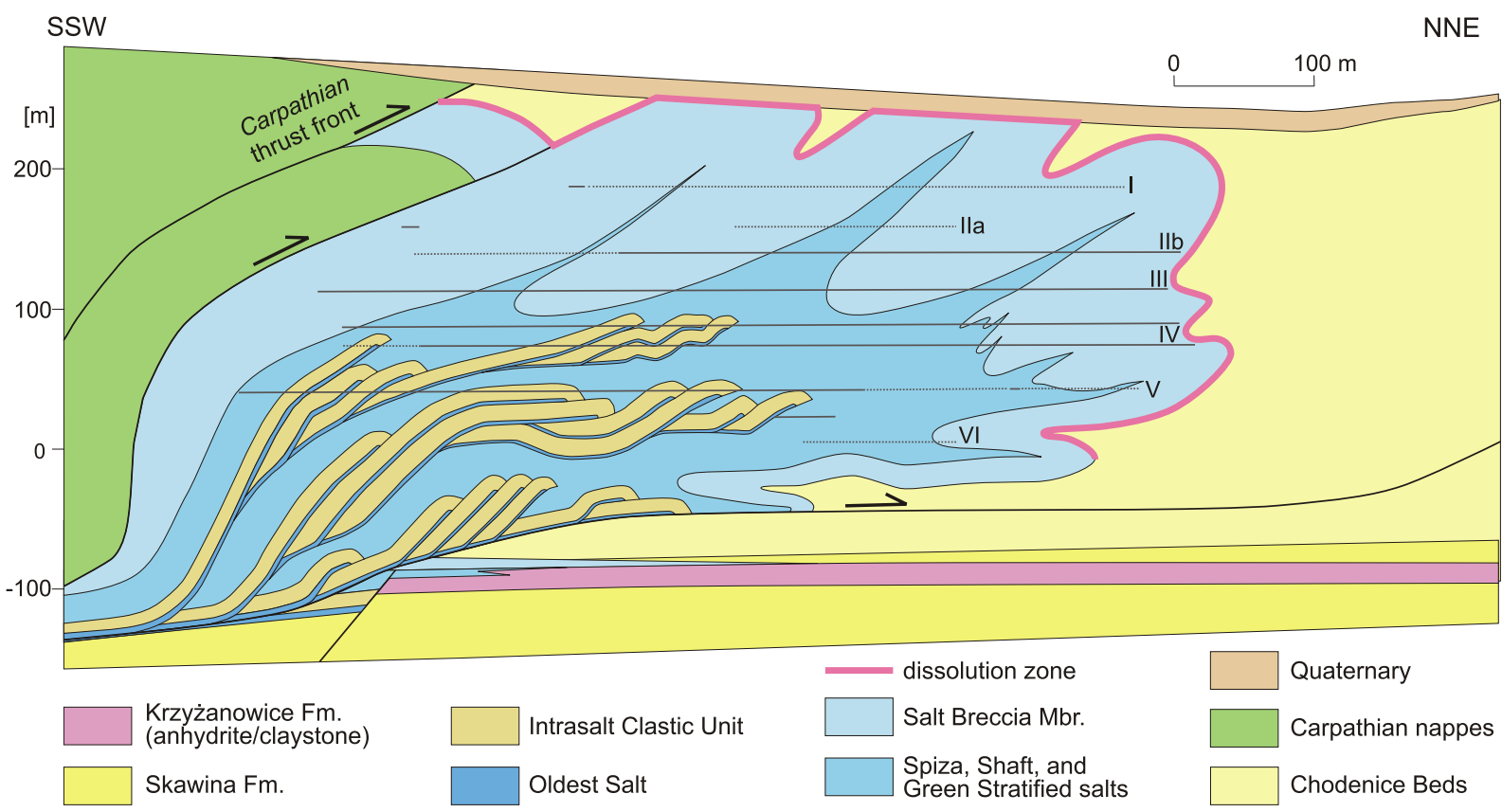

Fig. 12. Simplified cross-section through the area of the Wieliczka salt mine

Cross-section based on: 1 - mapped relationships of cross-section 8 of Gaweł (1962), itself based on observations from mine corridors (horizontal solid and dashed black lines where on or close to, respectively, the line of section; Roman numbers indicate mine levels), 2 - the mechanical stratigraphy of the Wieliczka Formation LES, and 3 -thickness variation in the Salt Breccia Mbr. and Intrasalt Clastic Unit (e.g., Bukowski, 1997); the level of the basal anhydrite layer is constrained by deep boreholes somewhat west of the section, but the basement fault and deep fold/thrust geometries below and to the south of the mine are speculative; location of cross-section indicated on Figure $6 \mathrm{~A}$ 


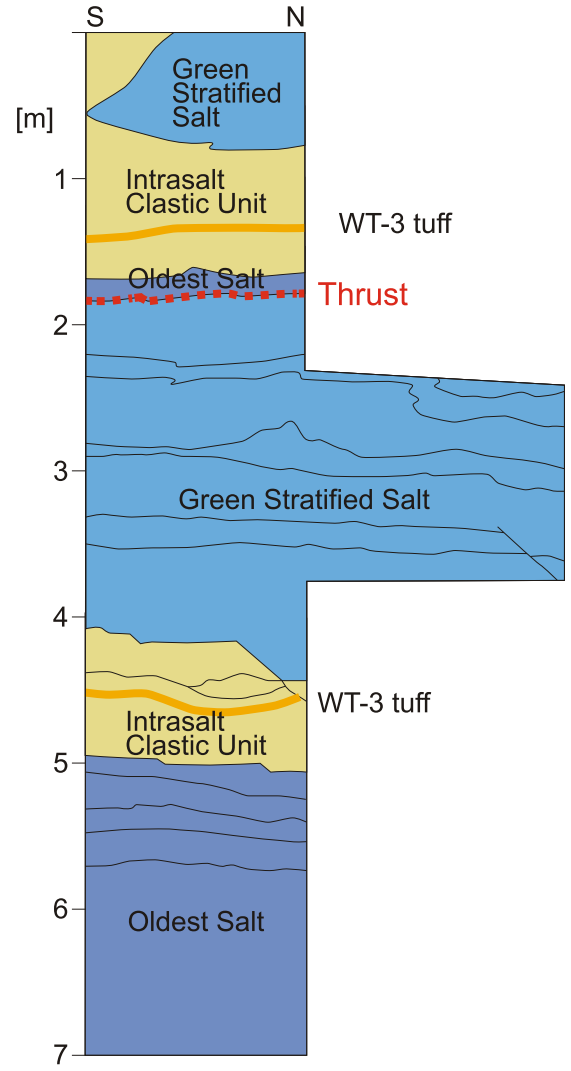

Fig. 13. Thrust duplication of oldest Wieliczka Formation sequences

Sketch of observed features in shaft drilled from Level VIII in the western part of the mine (Wiewiórka, 1974, unpubl. data); thrust fault caries thin sliver of Oldest Salt in hanging wall, in addition to the Intrasalt Clastic Unit (and WT-3 tuff; see Wiewiórka, 1979) and lowermost Green Stratified Salt; unit colours are those of Figure 5

evaporite basin, and sedimentary reworking of the evaporites themselves show that there was a depositional slope. For example, the Mid/Sub-salt Sandstone is interpreted as a submarine fan deposit sourced from the south (Bukowski, 1997). The presence of a slope during evaporite deposition suggests that the southern part of the salt basin was being uplifted, possibly by early deformation within the Wieliczka Formation itself. More early shortening could be introduced into Figure 12 by increasing the number and complexity of the imbricate thrusts.

The most frontal shallow geometries do not show any evidence of having been influenced by the overlying triangle-zone backthrust (Fig. 4). Instead, the folds are all strongly asymmetric toward the foreland (Fig. 12). The backthrust may have been a discrete detachment, without any associated shear deformation in its footwall, it may have postdated much of the deformation in the Wieliczka area, or it is simply too far to the north for its effects to be seen in the vicinity of the mine. The second possibility would be compatible with ongoing deformation during and after evaporite deposition but is pure speculation.

We interpret the large-scale geometry as being entirely due to the regional tectonics for several reasons. First, the structure is parallel to the Carpathian thrust front, and published sections show the southernmost part of the Wieliczka structure involved in Carpathian thrust imbricates (e.g., Poborski and Skoczylas-
-Ciszewska, 1963; Garlicki, 1968). Second, it is part of a triangle zone, which is a common frontal feature of fold-and-thrust belts. Third, different levels appear to have roughly the same amount of shortening, which would not be expected for soft-sediment deformation. And fourth, the geometries and likely origin in overthrust shear imply a progressive deformation history, not a sudden event or series of events. None of these proves the tectonic origin but, when taken together, they suggest that a tectonic origin is the interpretation of least astonishment and coincidence.

\section{SMALL-SCALE DEFORMATION}

\section{ORIGIN AND RELATIVE TIMING OF EXTENSION} AND CONTRACTION

The Green Stratified, Shaft, and Spiza salts experienced net shortening along with supra- and subjacent layers. They also flowed differentially to accommodate differences in fold geometries above and below, thereby thinning in places and thickening in others. Although this complex deformation is not readily apparent in the halite beds themselves, it is recorded in the meso- to small-scale structures that are nicely exposed in the interbedded siliciclastics of the mine (Figs. 7, 8 and 10). Again, however, a long-standing debate concerns whether all these features, even if the large-scale deformation was tectonic, were also tectonic or whether at least some of them could have been caused by soft-sediment deformation during evaporite deposition.

Whereas the large- and meso-scale features are entirely contractional, the small-scale structures are both contractional and extensional. Extensional structures can readily develop during shortening, especially in overthrust shear (Ramsay et al., 1983). As shown by the finite strain ellipses in Figure 11, backlimbs are in the extensional field during much of the history, but forelimbs enter the extensional field only if they rotate to overturned orientations. In our small study area in the Wieliczka salt mine, all limbs, regardless of orientation, display boudinage and extensional faults. Critically, forelimbs dipping toward the foreland, which have always been in the contractional field and are therefore commonly thickened (Fig. 7B), have plentiful small-scale extensional structures (Figs. 7A, B and 10C-E). Thus, although overthrust shear may have contributed to some of the small-scale extension, it cannot explain all the observed cases.

Another mechanism for developing extensional structures during shortening is common for competent layers embedded in ductile halite (Rowan et al., 2019). Although strong layers maintain their coherency at low values of strain, increased shortening leads to bed disruption and boudinage. However, this is concentrated beneath synclines and in the cores of anticlines, while fold limbs are generally characterized by coherent, albeit folded, layers. In the analysed area at Wieliczka, boudinage is practically ubiquitous (Figs. 7, 8 and 10), suggesting that, again, although this process may have contributed to the deformation, it cannot by itself account for all the observed extension.

The question of origin ultimately comes down to determining whether the contractional and extensional structures were coeval or part of separate deformation events. A separate origin is implied by the very different orientations of the two types of structures. Whereas the meso- to small-scale contractional structures have essentially identical orientations and asymmet- 
ric geometries (vergent toward the north) as the large-scale folds, the limited number of normal faults measured implies extension in an ENE-WSW direction (Fig. 9). Distinct origins and timing are also suggested by the arguments cited above, in which the ubiquitous distribution of boudinage cannot be explained by either shortening in overthrust shear or layer disruption during contraction.

Several observations indicate that extension predated shortening and had a non-tectonic origin. First, layers in close proximity to each other display very different amounts of extension, with some layers barely extended and others having large gaps between boudins (Fig. 10A, C). This is compatible with an episodic process during deposition but is unlikely if the extension was later and orogenic in nature. Second, there are many examples of boudins that are now overlapped, presumably due to shortening after formation (Fig. 10D, F). When combined with the ubiquitous distribution and different orientations, the evidence is fairly strong that early extension was followed by later contraction. Having said that, there are also cases, although relatively rare, where late extension appears to have modified shortening structures. For example, the small extensional faults in Figure 10E were not rotated by folding. Thus, there was likely some component of synorogenic extension, possibly due to limb extension during overthrust shear.

\section{MODEL}

The direction of the palaeo-slope is generally assumed to have been toward the north due to the topography generated by the Carpathian thrust front (e.g., Ślączka and Kolasa, 1997; Burliga et al., 2018), although there may have been local variations due to fan morphology. However, there are no published orientation data for structures clearly associated with sediment reworking. Measured attitudes are for features interpreted as tectonic, which do show roughly north-directed movement (Tarka, 1988; Cyran, 2008; see also Fig. 9A).

Here, however, we document a limited number of extensional faults that are highly oblique to the main tectonic structures. Moreover, we argue that the boudinage and extensional faults observed in the study area mostly predated the orogenic deformation and were caused by syndepositional gravity gliding. Thus, the orientations of the extensional faults, corrected for later orogenic folding (dashed lines, Fig. 9B), indicate that movement prior to shortening was toward the east and northeast. One interpretation is that this was the direction of the palaeo-slope. Interestingly, to the east and south-east of Wieliczka is the Gdów Embayment, so named because of the reentrant in the frontal Carpathian thrust. In fact, this was a significant depocenter just prior to evaporite deposition (Alexandrowicz, 1965; Garlicki, 1971; Krzywiec et al., 2012), with up to at least $1000 \mathrm{~m}$ of Skawina Formation strata that were later inverted. This is consistent with the Skawina Formation beneath the Wieliczka salt mine thickening from $45 \mathrm{~m}$ in the west to $350 \mathrm{~m}$ in the east, toward the Gdów Embayment (Wiewiórka, 1988).

Even if there was no ongoing tectonic subsidence during evaporite deposition, the Gdów Embayment would have remained a depocentre during the salinity crisis due to loading subsidence and differential compaction alone (Krzywiec et al., 2012). This is compatible with published studies of parts of the Wieliczka Formation First, the Green Stratified Salt IV is interpreted as predominantly a slump deposit that thickens toward the east (Gonera et al., 2012). Second, the Salt Breccia Member is also a mass-wasting deposit (Ślaczka and Kolasa, 1997) that thickens in the same direction (e.g., Szybist, 1975). Third, ripples in intra-Spiza siliciclastics show consistent east to northeast flow directions (Ślączka and Kolasa, 1997); although they were interpreted as recording longshore currents, we suggest instead that they might represent downslope flow.

Where was the study area located during deposition? Ślaczka and Kolasa (1997) reported $10 \mathrm{~km}$ of displacement of Middle Miocene rocks toward the north during the Late Miocene. Moreover, the study area is in the upper, southern portion of the mine (Fig. 6B), which, after unfolding of the geometries in our cross-section (Fig. 12), would have been a further $2 \mathrm{~km}$ to the south. Given the lack of hard constraints, we place the study area a somewhat arbitrary $10 \mathrm{~km}$ south of its current location (Fig. 14). Assuming that the Gdów depocentre was still actively subsiding, as explained above, the regional palaeo-slope would have been toward the east or north-east. The early boudinage and extensional faults suggest that the area was in the extensional province of the gravitational system, i.e., in the upper portions of the topographic slope. Subsequent Carpathian folding and thrusting would have translated the area northward to its current position (Fig. 14). Different estimates of the amount of shortening would not significantly change the model scenario.

If the small-scale extensional structures are synsedimentary, could not some of the small-scale contractional structures in the study area have a similar origin? Although possible, we doubt this for two reasons. First, gravity-driven systems at any given time are generally separated into extensional, translational, and contractional provinces (see, e.g., Rowan, 2020). Thus, the coeval shortening would have been located farther downslope, i.e., in the deeper levels of the eastern part of the mine or even farther east. Second, it is unlikely that gravity-driven contraction would have overprinted the extension. Typically it is just the opposite that occurs: as the sediments prograde and/or tectonic uplift progresses toward the foreland, both the extensional and contractional provinces would have correspondingly shifted in the same direction (e.g., Rowan, 2020). Thus, it is more likely to have early contractional structures overprinted by extension, but we have observed the opposite relationship in our small study area.

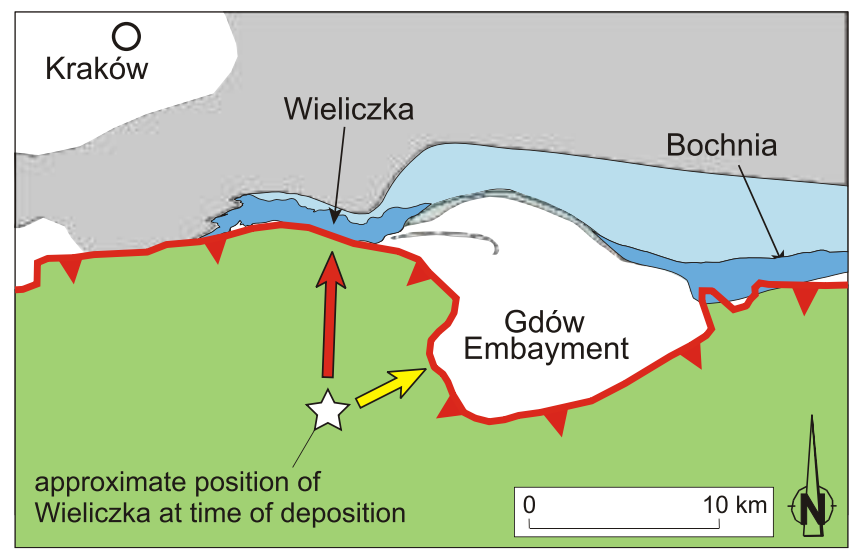

\section{Fig. 14. Proposed evolutionary model for the Wieliczka area}

Small area of map in Figure 2 showing the location of Wieliczka, Bochnia, the Carpathian thrust front, and the Gdów Embayment (colours and symbols as in Figure 2); the white star shows the approximate depositional position of Wieliczka relative to the foreland, with the yellow arrow indicating ENE-directed downslope syndepositional gravity gliding into the deeper basin of the embayment and the red arrow showing subsequent $\mathrm{N}$-directed orogenic translation of $\sim 10 \mathrm{~km}$ 


\section{DISCUSSION AND CONCLUSIONS}

In this contribution, we have analysed the intrasalt structures within the Wieliczka salt mine at a range of scales. Our goals have been several: first, to understand the large-scale geometries and determine their likely origin and development; and second, to evaluate the meso- to small-scale structures and ascertain whether they are tectonic or syndepositional in origin.

Numerous cross-sections through the Wieliczka area have been published. Although most are somewhat to largely similar in that they display a series of asymmetric, cascading folds, they lack an adequate explanation of why the folds take the form they do. We have attempted to provide a subregional context, specifically suggesting that they formed due to overthrust shear between two diverging thrust detachments, one at the base of the salt sequence and one at the base of the overriding Carpathian frontal nappe. This process generates folds that are asymmetric and inclined at upper levels but become more recumbent at lower levels. The overall deformed wedge is part of a triangle zone developed during the Carpathian Orogeny.

An additional critical factor in determining the geometries is the mechanical stratigraphy of the Wieliczka Formation LES. Although complex at the small scale, it is relatively simple at the large scale, comprising four dominant intervals with different strengths and thicknesses (Fig. 5). The two basal units are thin (roughly $10 \mathrm{~m}$ each), with a weak halite (Oldest Salt) overlain by strong siliciclastics (Intrasalt Clastic Unit). This results in thrust imbricates, with a relatively short spacing, comprising mostly the strong layer but also a thin sliver of the salt (Fig. 13). The imbricates are largely decoupled from the thicker, upper strong unit (Salt Breccia Mbr.) by a relatively thick sequence of weak, halite-dominated layers (Green Stratified, Shaft, and Spiza salts). Thus, the upper part of the deformed wedge consists of long-wavelength cuspate-lobate folds, with the anticlines cored by narrow spines of salt (Fig. 12).

Complex small-scale extensional and contractional structures are ubiquitous and best displayed by the siliciclastic layers interbedded with the halite layers. They have been attributed in the literature to either tectonics or soft-sediment deformation. We are able to demonstrate, albeit only in a small area of the mine and with limited data, that most of the extension predated the shortening, and interpret that whereas the contractional structures were part of the north-vergent tectonic deformation, the boudinage and extensional faulting were caused by gravitydriven downslope movement during evaporite deposition. Moreover, we postulate that the palaeo-slope dipped toward the east to north-east, into the Gdów Embayment, which was a prominent depocentre prior to, and likely during, evaporite deposition.

We emphasize that the results presented here are preliminary. Again, we conducted no mapping of the large-scale structure ourselves and we analysed the small-scale structures only in a limited area of the mine. Thus our models and conclusions should be taken as a starting point for further work. It is only by additional analysis that our ideas can be tested, refined, or disproven. Specifically, we highlight several avenues for continued research. First, some aspects of our large-scale cross-section need to be investigated, for example: whether or not the
Oldest Salt is commonly emplaced above younger salts (Fig. 13); whether the Intrasalt Clastic Unit typically forms stacked thrust imbricates (Fig. 13); and whether all instances of Skawina Beds are indeed reworked. Second, the small-scale structures need to be measured and evaluated in more areas, ideally throughout the mine from west to east and from the most hinterland, shallow levels to the deeper, frontal levels. Do the extensional features maintain a consistent relative timing, distribution, and orientation, or are there changes that could be related to variations in the palaeo-slope? Are there any early, syndepositional contractional structures in areas that would have been located farther down the palaeo-slope? Do the structures change style, intensity, or orientation from older to younger layers of the evaporite sequence? Third, similar analyses should be conducted at the Bochnia salt mine because it is located on the other side of the Gdów Embayment, and any early extensional structures might have been directed towards the west and north-west into the depocentre. Finally, the results of detailed structural studies should be combined with the wealth of seismic and borehole data to build an integrated, three-dimensional model of the Miocene geometry and evolution of the Zgłobice triangle zone in the area of the two salt mines and the intervening Gdów Embayment.

The results of this study should be of interest to those working not only on Wieliczka itself but also on the structure and stratigraphy of the Miocene evaporite sequences throughout the long arc of the Carpathians. But the findings could also have wider application. Numerous foreland basin salt deposits have similar depositional and deformational aspects. Probably the closest analog is the Ebro Basin of the Southern Pyrenees (e.g., Krzywiec and Vergés, 2007). Not only are the Paleogene evaporites involved in the frontal deformation, but they contain interbedded siliciclastics and reworked/slumped evaporites (e.g., Carrillo et al., 2014). Another analog is the Kuqa Basin of NW China, in the foothills of the Tien Shan Mountains, where the frontal thrust is detached in Palaeogene LES that have significant lateral and hinterland-to-foreland variations in the proportions and facies of interbedded siliciclastics (e.g., Liu et al., 2008; Izquierdo-Llavall et al., 2018).

Ultimately, a better understanding of the intrasalt structure exposed within the Wieliczka salt mine is a worthy goal in and of itself. This is a world-famous site with a long history not only of exploitation but also of general wonder and awe at both the natural and man-made structures. Many of the visitors are geoscientists, whether they are there on field trips or just as tourists, and any ideas that may increase our appreciation of the evaporite geology and stimulate further study are surely worthwhile.

Acknowledgements. The authors thank Kopalnia Soli "Wieliczka" S.A. for access to the non-public portions of the mine and for archived data. MR acknowledges his mother-inlaw, Dr. M. Komorowska-Błaszczyńska, a geologist who first took him to the Wieliczka mine and who actually published on the Miocene structure and stratigraphy, including the evaporites, of the Polish Carpathians and their foredeep (e.g., Komorowska-Błaszczyńska, 1965). S. Burliga, P. Kukla, and C. Leitner provided helpful reviews that improved the paper. 


\section{REFERENCES}

Aldrovandi, U., 1648. Musaeum Metallicum in Libros IIII. Io. Baptistæ Ferronij, Bologna.

Alexandrowicz, S.W., 1965. La Molasse miocène aux environs de Gdów. Bulletin of the Polish Academy of Sciences, 13: 49-57.

Alexandrowicz, S.W., Garlicki, A., Rutkowski, J., 1982. Podstawowe jednostki litostratygraficzne miocenu zapadliska przedkarpackiego (in Polish). Geological Quarterly, 26 (2): $470-471$.

Anonym, 1670. A relation, concerning the sal-gemme-mines in Poland; communicated by a curious gentleman of Germany, who, some years since, descended himself into those mines, to the depth of 200 fathoms, and was led about in them for the space of three hours. Philosophical Transactions of the Royal Society, 5: 1099-2002.

Báldi, K., Velledits, F., Ćorić, S., Lemberkovics, V., L rincz, K., Shevelev, M., 2017. Discovery of the Badenian evaporites inside the Carpathian Arc: implications for global climate change and Paratethys salinity. Geologica Carpathica, 68: 193-206.

Bénard, R., 1768. Vue générale de la mine de sel de Wieliczka en Pologne près Cracovie (in French). In: Encyclopédie, ou Dictionnaire Raisonné des Sciences, des Arts et des Métiers (eds. D. Diderot and J. d'Alembert). Septieme Collection, Paris.

Biot, M.A., 1961. Theory of folding of stratified viscoelastic media and its implications in tectonics and orogenesis. GSA Bulletin, 72: $1595-1620$

Boczkowski, F., 1843. O Wieliczce pod Wzgledem History Naturalnej, Dziejów i Kąpieli (in Polish). Nakładem Wawrzyńca Pisza, Bochnia.

Brudnik, K., Przybyło, J., Stecka, J., 2000. Geological structure and hydrogeological situation of the Crystal Caves' zone (in Polish with English summary). Studia Naturae, 46: 35-57.

Bukowski, K., 1997. Sedimentation of clastic strata associated with Miocene salts in Wieliczka (Southern Poland). Slovak Geological Magazine, 3: 157-163.

Bukowski, K., 2011. Badenian saline sedimentation between Rybnik and Dębica based on geochemical, isotopic and radiometric research (in Polish with English summary). Rozprawy Monografie, 236.

Bukowski, K., de Leeuw, A., Gonera, M., Kuiper, K., Krzywiec, P., Peryt, D., 2010. Badenian tuff levels within the Carpathian orogenic front (Gdów-Bochnia area, Southern Poland): radio-isotopic dating and stratigraphic position. Geological Quarterly, 54 (4): 449-464.

Bukowski, K., Dąbroś, K., Przybyło, J., Włodarczyk- urek, E., Źróbek, M., 2019. Salt deposition in the Wieliczka area and its exposure in the salt mine. NCSEE 8th International Workshop on Neogene of Central and South-Eastern Europe: 125-135.

Burliga, S., Krzywiec, P., Dąbroś, K., Przybyło, J., Włodarczyk, E., Żróbek, M., Słotwiński, M., 2018. Salt tectonics in front of the Outer Carpathian thrust wedge in the Wieliczka area (S Poland) and its exposure in the underground salt mine. Geology, Geophysics and Environment, 44: 71-90.

Carrillo, E., Rosell, L., Ortí, F., 2014. Multiepisodic evaporite sedimentation as an indicator of palaeogeographical evolution in foreland basins (south-eastern Pyrenean basin, Early-Middle Eocene). Sedimentology, 61: 2086-2112.

Casey, M., Huggenberger, P., 1985. Numerical modelling of finite-amplitude similar folds developing under general deformation histories. Journal of Structural Geology, 7: 103-114.

Cyran, K., 2008. Tektonika mioceńskich złó soli w Polsce (in Polish). Ph.D. thesis, Akademia Górniczo-Hutnicza im. Stanisława Staszica, Wydział Geologii, Geofizyki i Ochrony Środowiska Zakład Geologii Zło owej i Górniczej, AGH.

Davis, D.M., Engelder, T., 1985. The role of salt in fold-and-thrust belts. Tectonophysics, 119: 67-88.

de Leeuw, A., Bukowski, K., Krijgsman, W., Kuiper, K.F., 2010. Age of the Badenian salinity crisis; impact of Miocene climate variability on the circum-Mediterranean region. Geology, $\mathbf{3 8}$ 715-718. de Leeuw, A., Tulburec, M., Kuiper, K.F., Melinte-Dobrinescu, M.C., Stoica, M., Krijgsman, W., 2018. New ${ }^{40} \mathrm{Ar} /{ }^{39} \mathrm{Ar}$, magnetostratigraphic and biostratigraphic constraints on the termination of the Badenian salinity crisis: indications for tectonic improvement of basin interconnectivity in southern Europe. Global and Planetary Change, 169: 1-15.

Dietrich, D., Casey, M., 1989. A new tectonic model for the Helvetic nappes. Geological Society Special Publications, 45: 47-63.

Fischer, M.P., Woodward, N.B., Mitchell, M.M., 1992. The kinematics of break-thrust folds. Journal of Structural Geology, 14: 451-460.

Garlicki, A., 1968. Autochthonous salt series in the Miocene of the Carpathian Foredeep, between Skawina and Tarnów (in Polish with English summary). Biuletyn Instytutu Geologicznego, 215: 5-78.

Garlicki, A., 1971. Rock salt deposit Łę kowice on Raba (in Polish with English summary). Geological Quarterly, 15 (4): 930-946.

Garlicki, A., 1979. Sedimentation of Miocene salts in Poland (in Polish with English summary). Prace Geologiczne, 119.

Garlicki, A., 1994. Formalne jednostki litostratygraficzne miocenu formacja z Wieliczki (in Polish). Przegląd Geologiczny, 42: 26-28.

Gawet, A., 1962. The geological structure of the Wieliczka salt deposit (in Polish with English summary). Prace Instytutu Geologicznego, 30: 305-331

Gedl, P., Worobiec, E., 2020. Origin and timing of palaeovalleys in the Carpathian foredeep basement (Sędziszów MałopolskiRzeszów area, SE Poland) in the light of palynological studies. Marine and Petroleum Geology, 115, 104277

Ghosh, S.K., 1966. Experimental tests of buckling folds in relation to strain ellipsoid in simple shear deformations. Tectonophysics, 3: $169-185$.

Gibson, R.G., Gray, D.R., 1985. Ductile-to-brittle transition in shear during thrust sheet emplacement, Southern Appalachian thrust belt. Journal of Structural Geology, 7: 513-525.

Głuszyński, A., Aleksandrowski, P., 2016. A deep paleovalley in the floor of the Polish Carpathian Foredeep basin near Pilzno and its control on Badenian (Middle Miocene) evaporite facies. Geological Quarterly, 60 (2): 493-516.

Gonera, M., Bukowski, K., D’Obryn, K., Wiewiórka, J., 2012. Foraminifera in slump deposits of the Badenian (Middle Miocene) Green Stratified Salt in Wieliczka, Poland. Geological Quarterly, 56 (4): 869-880.

Hrdina, J.N., Hrdina, L.E., 1842. Geschichte der Wieliczkaer Saline. Carl Gerold, Wien.

Hudec, M.R., Jackson, M.P.A., 2006. Advance of allochthonous salt sheets in passive margins and orogens. AAPG Bulletin, 90 1535-1564.

Izquierdo-Llavall, E., Roca, E., Xie, H., Pla, O., Muñoz, J.A., Rowan, M.G., Yuan, N., Huang, S., 2018. Influence of overlapping décollements, syntectonic sedimentation, and structural inheritance in the evolution of a contractional system: the central Kuqa fold-and-thrust belt (Tian Shan Mountains, NW China). Tectonics, 37, doi: 10.1029/2017TC004928

Jones, P.B., 1997. The Carpathians of Southern Poland: thrust tectonics or wedge tectonics (abs.). AAPG Search and Discovery Article \#90942.

Jucha, S., 1974. Uło enie przestrzenne i rozwój facjalny miocenu autochtonicznego oraz jego stosunek do nasunięcia karpacko-stebnickiego (in Polish). Zeszyty Naukowe AGH Geologia, 22: 9-20.

Kolasa, K., Ślączka, A., 1985a. Sedimentary salt megabreccias exposed in the Wieliczka mine, Fore-Carpathian Depression. Acta Geologica Polonica, 35: 221-230.

Kolasa, K., Ślaczka, A., 1985b. Some remarks on the Wieliczka salt deposit genesis (in Polish with English summary). Studia i Materiały do Dziejów up Solnych w Polsce, 14: 7-49.

Komorowska-Błaszczyńska, M., 1965. The anhydrite-less island in the profiles of the Rzeszów foreland. Bulletin l'Academie Po- 
Ionaise Sciences, Série Sciences Géologiques Géographique, 13: $273-280$.

Krzywiec, P., 2001. Contrasting tectonic and sedimentary history of the central and eastern parts of the Polish Carpathian foredeep basin - results of seismic data interpretation. Marine and Petroleum Geology, 18: 13-38.

Krzywiec, P., Vergés, J., 2007. Role of the foredeep evaporites in wedge tectonics and formation of triangle zones: comparison of the Carpathian and Pyrenean thrust fronts. In: Thrust Belts and Foreland Basins: from Fold Kinematics to Petroleum Systems (eds. O. Lacombe, J. Lavé, F. Roure and J. Vergés): 383-394. Frontiers in Earth Sciences, Springer, Heidelberg.

Krzywiec, P., Aleksandrowski, P., Florek, R., Siupik, J., 2004. The structure of the Outer Carpathians orogenic front: an example of the Miocene Zgłobice Unit between Brzesko and Wojnicz (SE Poland) - new data, new models, new questions (in Polish with English summary). Przeglad Geologiczny, 52: 1051-1059.

Krzywiec, P., Wysocka, A., Oszczypko, N., Mastalerz, K., Papiernik, B., Wróbel, G., Oszczypko-Clowes, M., Aleksandrowski, P., Madej, K., Kijewska, S., 2008. Evolution of the Miocene deposits of the Carpathian Foredeep in the vicinity of Rzeszów (the Sokołów-Smolarzyny 3D seismic survey area) (in Polish with English summary). Przegląd Geologiczny, 56: 232-244.

Krzywiec, P., Bukowski, K., Oszczypko, N., Garlicki, A., 2012. Structure and Miocene evolution of the Gdów tectonic "embayment" (Polish Carpathian Foredeep) - a new model based on reinterpreted seismic data. Geological Quarterly, 56 (4): 907-920.

Krzywiec, P., Oszczypko, N., Bukowski, K., Oszczypko-Clowes, M., Śmigielski, M., Stuart, F.M., Persano, C., Sinclair, H.D. 2014. Structure and evolution of the Carpathian thrust front between Tarnów and Pilzno (Pogórska Wola area, southern Poland) - results of integrated analysis of seismic and borehole data. Geological Quarterly, 58 (3): 399-416.

Liu, J., Wang, Q., Lin, C., Zhang, L., Lei, Y., Hu, G., Hu, B., 2008. Sequence and systems tract of Paleogene Kumugeliemu Group in western Kuqa Depression, Tarim Basin. Petroleum Exploration Development, 35: 651-656.

Manz, R., Wickham, J., 1978. Experimental analysis of folding in simple shear. Tectonophysics, 44: 79-90.

Maślankiewicz, K., 1965. Z dziejów górnictwa solnego w Polsce (in Polish). Wydawnictwa Naukowo-Techniczne, Warszawa.

Nemčok, M., Krzywiec, P., Wojtaszek, M., Ludhová, L., Klecker, R., Sercombe, W.J., Coward, M.P., 2006. Tertiary development of the Polish and eastern Slovak parts of the Carpathian accretionay wedge: insights from balanced cross-sections. Geologica Carpathica, 57: 355-370.

Niedźwiedzki, J., 1883-1886. Stosunki geologiczne formacyi solonośnej Wieliczki i Bochni (in Polish). Kosmos, 8 (1883): 137-159, 387-401, 483-492; 9 (1884): 565-580, 717-743; 11 (1886): $137-155$

Oszczypko, N., 1997. The Early-Middle Miocene Carpathian peripheral foreland basin (Western Carpathians, Poland). Przegląd Geologiczny, 45: 1054-1063.

Oszczypko, N., 1998. The Western Carpathian foredeep: development of the foreland basin in front of the accretionary wedge and its burial history (Poland). Geologica Carpathica, 49: 1-18.

Oszczypko, N., 2006. Late Jurassic-Miocene evolution of the Outher Carpathian fold-and-thrust belt and its foredeep basin (Western Carpathians, Poland). Geological Quarterly, 50 (1): 169-194.

Oszczypko, N., Krzywiec, P., Popadyuk, I., Peryt, T., 2006. Carpathian foredeep basin (Poland and Ukraine): its sedimentary, structural, and geodynamic evolution. AAPG Memoir, $\mathbf{8 4}$ 293-350.

Papp, A., Cicha, I., Seneš, J., Steininger, F., 1978. M4 - Badenien (Moravien, Wielicien, Kosovien). Chronostratigraphie und Neostratotypen, Miozän der Zentralen Paratethys, 6. VEDA, Bratislava.

Peryt, T.M., 2006. The beginning, development and termination of the Middle Miocene Badenian salinity crisis in Central Paratethys. Sedimentary Geology, 188-189: 379-396.
Peryt, T.M., Kovalevich, V.M., 1997. Association of redeposited salt breccias and potash evaporites in the lower Miocene of Stebnyk (Carpathian foredeep, west Ukraine). Journal of Sedimentary Research, 67: 913-922.

Poborski, J., 1965. Historical development of views on the geological structure of the salt beds of Wieliczka (in Polish with English summary). Studia i Materiały do Dziejów up Solnych w Polsce, 1: $37-54$.

Poborski, J., Skoczylas-Ciszewska, K., 1963. Miocene in the zone of the Carpathian overthrust in the area of Wieliczka and Bochnia (in Polish with English summary). Rocznik Polskiego Towarzystwa Geologicznego, 33: 339-348.

Poltowicz, S., 1977. Tectonic evolution of the rock salt deposits in Wieliczka and Barycz (in Polish with English summary). Rocznik Polskiego Twarzystwa Geologicznego, 47: 279-299.

Połtowicz, S., 1994. Znaczenie badeńskiej formacji solonośnej w tektonogenezie polskich Karpat fliszowych (in Polish). Geologia Kwartalnik AGH, 20: 59-75.

Połtowicz, S., 2004. The Stebnik and Zgłobice Units in the Polish Carpathians structure (in Polish with English summary). Kwartalnik AGH Geologia, 30: 85-120.

Pusch, G.G., 1824. Geognostich-bergmännische Reise durch einen Theil der Karpathen, Ober- und Nieder-Ungarn Ausgestellt im Jahre 1821. Leipzig.

Ramberg, H., 1960. Relationship between length of arc and thickness of ptygmatically folded veins. American Journal of Science, 258: 36-46.

Ramsay, J.G., 1982. Rock ductility and its influence on the development of tectonic structures in mountain belts. In: Mountain Building Processes (ed. K. Hsü): 111-127. Academic Press, London.

Ramsay, J.G., Huber, M.I., 1987. The Techniques of Modern Structural Geology, 2: Folds and Fractures. Academic Press, London.

Ramsay, J.G., Casey, M., Kligfield, R., 1983. Role of shear in development of the Helvetic fold-thrust belt of Switzerland. Geology, 11: 439-422.

Roure, F., Roca, E., Sassi, W., 1993. The Neogene evolution of the outer Carpathian flysch units (Poland, Ukraine and Romania): kinematics of a foreland/fold-and-thrust belt system. Sedimentary Geology, 86: 177-201.

Rowan, M.G., 2020. Gravity-driven failure of continental margins. In: Regional Geology and Tectonics, 1: Principles of Geologic Analysis (eds. N. Scarselli, J. Adam, D. Chiarella, D.G. Roberts and A.W. Bally): 205-234. Elsevier, Amsterdam.

Rowan, M.G., Kligfield, R., 1992. Kinematics of large-scale asymmetric buckle folds in overthrust shear: an example from the Helvetic nappes. In: Thrust Tectonics (ed. K.R. McClay): 165-173. Chapman and Hall, London.

Rowan, M.G., Urai, J.L., Fiduk, J.C., Kukla, P.A., 2019. Deformation of intrasalt competent layers in different modes of salt tectonics. Solid Earth, 10: 987-1013.

Sanderson, D.J., 1979. The transition from upright to recumbent folding in the Variscan fold belt of southwest England: a model based on the kinematics of simple shear. Journal of Structural Geology, 1: 171-180.

Schober, C.G., 1750. Physikalische Nachricht von den pohlnischen Salzgruben Wieliczka und Bochnia. Hamburgisches Magazin der Gesammelte Schriften zum Unterricht und Vergnügen aus der Naturforschung und den Angenehmen Wissenschaften Überhaupt, 6: 115-155.

Schröter, A., 1564. Regni Poloniæ salinarum Vieliciensium descriptio carmine elegiaco, iam denuo ab ipso authore Adamo Schrötero revisa et aucta Ex Officina Typographico Mathiæ Wirzbiętæ, Cracoviæ.

Siemion, I.Z., 1991. Obserwacje i doświadczenia naukowe Chrystiana Gottlieba Schobera (in Polish). Kwartalnik Historii Nauki i Techniki, 36: 159-174.

Ślaczka, A., Kolasa, K., 1997. Resedimented salt in the Northern Carpathians Foredeep (Wieliczka, Poland). Slovak Geological Magazine, 3: 135-155.

Ślączka, A., Kruglov, S., Golonka, J., Oszczypko, N., Popadyuk, I., 2006. Geology and hydrocarbon resources of the Outer 
Carpathians, Poland, Slovakia, and Ukraine: general geology. AAPG Memoir, 84: 221-258.

Stewart, S.A., 1999. Geometry of thin-skinned tectonic systems in relation to detachment layer thickness in sedimentary basins. Tectonics, 18: 719-732.

Szybist, A., 1975. Geological studies on brecciated part of Wieliczka rock-salt deposit (in Polish with English summary). Przeglad Geologiczny, 23: 428-431.

Tarka, R., 1992. Tectonics of some salt deposits in Poland based on mesostructural analysis (in Polish with English summary). Prace Państwowego Instytutu Geologicznego, 137.

Tarka, R., Wiewiórka, J., Barmuta, P., Brudnik, K., 1988 Wieliczka - mesostruktural evidence of tectogenesis (in Polish with English summary). Przegląd Geologiczny, 36: 572-577.

Tołwiński, K., 1956. The chief tectonic elements of the Carpathian Mts. (in Polish with English summary). Acta Geologica Polonica, 6: 75-226.

Urai, J.L., Spiers, C.J., Zwart, H.J., Lister, G.S., 1986. Weakening of rock salt by water during long-term creep. Nature, 324: 554-557.

Weijermars, R., Jackson, M.P.A., Vendeville, B.C., 1993. Rheological and tectonic modeling of salt tectonic provinces. Tectonophysics, 217: 143-174.
Wiewiórka, J., 1974. Level of the oldest rock-salt in the stratified salt deposit of Wieliczka (in Polish with English summary). Studia i Materiały do Dziejów up Solnych w Polsce, 3: 17-38.

Wiewiórka, J., 1979. Przewodnie poziomy tufitowe w kopalni soli Wieliczka (in Polish). Sprawozdania z Posiedzeń Komisji Naukowych PAN, Oddział w Krakowie, 21: 176-178.

Wiewiórka, J., 1988. Geological conditions of salt exploitation in the Kraków Salt-Works (in Polish with English summary). In: The History of Kraków Salt-Works (eds. A. Jodłowski, J. Wiewiórka, J. Piotrowicz, A. Keckova, K. Dziwik and J. Wyrozumski): 37-70. Muzeum up Krakowskich, Wieliczka.

Wiewiórka, J., Charkot, J., Dudek, K., Gonera, M., 2008. Historic salt mines in Wieliczka and Bochnia. Geoturystyka, 4: 61-70.

Willis, B., 1893. Mechanics of Appalachian structure. U.S.G.S. Annual Report, 13: 217-281.

Zejszner, L., 1843. Krótki opis historyczny, geologiczny i górniczy Wieliczki (in Polish). B. Behr, Berlin.

ytko, K., Gucik, S., Ryłko, W., Oszczypko, N., Zając, R., Garlicka, I., Nemčok, J., Eliáš, M., Menčik, E., Dvořák, J., Stránik, Z., Rakus, M., Matějovská, O., 1989. Geological Map of the Western Outer Carpathians and their Foreland without Quaternary Formations. In: Geological Atlas of the Western Carpathians and their Foreland (eds. D. Poprawa and J. Nemčok). Polish Geological Institute, Warszawa. 